\title{
Gerir a diversidade: contributos da aprendizagem cooperativa para a construção de salas de aula inclusivas
}

\author{
Cláudia Tavares
}

Agrupamento de Escolas Nuno de Santa Maria, Tomar, Portugal

Isabel Sanches

Universidade Lusófona de Humanidades e Tecnologias, Portugal

\begin{abstract}
Resumo
A investigação-ação que levámos a cabo numa escola de $1^{\circ}$ ciclo do ensino básico, próxima da cidade de Tomar, em 2009-2010, no âmbito do mestrado em Educação Especial, foi o ponto de partida para a elaboração deste artigo. Teve como principal objetivo promover o sucesso na aprendizagem de um grupo de alunos, onde se encontrava inserida uma criança considerada com necessidades educativas especiais de caráter permanente com diagnóstico de galactosemia e défice cognitivo. Partindo do contexto educativo concreto desta turma de $2^{\circ}$ e $3^{\circ}$ anos de escolaridade, à qual tínhamos de prestar apoio como professora de educação especial, interviemos no sentido de fazer emergir um ambiente educativo inclusivo para cada aluno da turma. Através de uma cooperação efetiva entre docentes parceiros, gerámos mudanças nas metodologias, rompendo com algumas práticas tradicionais de sala de aula quando professores do ensino regular e educação especial se encontram no mesmo espaço pedagógico. Pela implementação sistemática de estratégias de aprendizagem cooperativa entre alunos e a aplicação de técnicas de recolha qualitativa de dados antes e após a intervenção - entrevista, observação naturalista, sociometria e pesquisa documental -, aumentámos a qualidade e a quantidade das suas aprendizagens e a sua participação nas atividades de sala de aula, promovendo, ao mesmo tempo, uma outra forma de 'olhar' a diferença.
\end{abstract}

Palavras-chave

Inclusão; Diversidade; Aprendizagem cooperativa; Investigação-ação

\section{Introdução}

O trabalho de investigação que desenvolvemos emergiu de uma inquietação que tem vindo a acompanhar a nossa prática pedagógica, 
enquanto docente de educação especial: a de procurar respostas educativas cada vez mais eficazes para, em colaboração com os docentes de ensino regular, conseguir uma efetiva inclusão social e académica dos alunos considerados com necessidades educativas especiais (NEE), promovendo aprendizagens significativas em contexto escolar e na construção dos seus projetos de vida. A diversidade de alunos que passou a frequentar a escola provocou um redimensionar do próprio conceito de diferença e uma impossibilidade de continuarmos (professores) indiferentes a tantas diferenças individuais e à persistência de um insucesso escolar generalizado que, como refere Perrenoud (2001), parece continuar a ser comodamente explicado como a "fatalidade do fracasso" (p. 17).

Ao obtermos uma visão mais alargada dos conceitos de 'diferença' e 'educação de qualidade', compreendemos que a verdadeira inclusão só pode ser concretizada na sala de aula. Não é retirando o(s) aluno(s) desse espaço, como se de um 'ser-problema-indesejado' se tratasse, mas retirando, sim, o professor do centro da aula. Tal mudança será viabilizada através da implementação de metodologias ativas que permitam a cada aluno, com ou sem NEE, construir o seu percurso em interação permanente com as pessoas que pertencem ao seu grupo e com ele vivenciam situações de aprendizagem, delas retirando conhecimento e experiência para a vida.

Por conseguinte, e na tentativa de inovar também nas nossas práticas, desde sempre contextualizadas em escolas de ensino secundário e de $2^{\circ} / 3^{\circ}$ ciclos do ensino básico, onde a intervenção do docente de educação especial é tradicionalmente realizada junto do professor da disciplina (apoio indireto aos alunos) ou em contexto extra-sala de aula, colocámos intencionalmente o enfoque da nossa investigação na turma e no trabalho em sala de aula. Foi nosso objetivo promover a inclusão educativa de todos os alunos e não só da aluna com maiores dificuldades de participação, aprendizagens e interação com os colegas, como tradicionalmente é feito. A partir deste enfoque, emergiu a seguinte questão de partida: Poderemos tornar esta sala de aula mais inclusiva, através de uma efetiva parceria pedagógica e da criação de situações de aprendizagem assentes em métodos da aprendizagem cooperativa?

No sentido de operacionalizar a nossa questão de partida, estipulámos os seguintes objetivos gerais para o nosso projeto: 
- promover a socialização de saberes académicos na turma, através de estratégias de diferenciação pedagógica baseadas no trabalho cooperativo entre os alunos;

- promover a inclusão da aluna 'caso' através do desenvolvimento de competências pessoais, sociais e académicas no seio da turma;

- alterar as dinâmicas da sala de aula, centradas no discurso do professor e no trabalho individual do aluno;

- aumentar a confiança da encarregada de educação da aluna 'caso' nos agentes educativos que trabalham com a sua educanda e a aceitação das características cognitivas da mesma;

- desenvolver a capacidade autocrítica e autorreflexiva, quer nos alunos, quer nas docentes.

\section{Contextualização teórica}

\section{Educação inclusiva: Uma escola de todos e para cada um}

O movimento inclusivo iniciado nos finais do século $X X$, impulsionado por conferências, acordos políticos e declarações mundiais, como sejam a Conferência de Jomtien (1990), a Declaração de Salamanca (1994), a Declaração de Madrid (2002), a Convenção sobre os Direitos das pessoas com deficiência (2007), entre outras, ainda não está consubstanciado em práticas consistentes no quotidiano da docência. No entanto, ajudou a questionar alguns dos princípios, tradicionalmente aceites, entre eles o de que ensinar a todos como se apenas de um se tratasse (Teodoro, 2006) não mais poderá continuar a competir, por um lado, com a heterogeneidade e diversidade dos 'clientes' das nossas escolas de hoje e, por outro, com os princípios de equidade e responsabilidade partilhada, defendidos pelas sociedades mais evoluídas. Se tal continuar a acontecer por mais tempo, corre-se o risco de, tal como refere Sanches (2005), "em breve, serem mais os excluídos que os incluídos" (p. 133), dadas as elevadas taxas de insucesso escolar a que continuamos a assistir nas nossas escolas. Não têm resolvido este problema as frequentes reorganizações curriculares, a panóplia de mecanismos, planos nacionais e planos educativos de reforço das aprendizagens, atualmente montados no sistema educativo português. 
O termo inclusão, que encerra em si um conjunto de princípios e direitos consagrados por lei, exige, sobretudo, a preparação da escola para atender todos os alunos, respeitando cada um na sua singularidade, sejam eles considerados ou não com NEE, únicos nas suas características físicas, psicológicas, raciais ou culturais. Como se encontra bem patente na Declaração de Salamanca (UNESCO, 1994), as escolas devem ajustar-se

a todas as crianças independentemente das suas condições físicas, sociais, emocionais, linguísticas ou outras. Neste conceito, terão de incluir-se crianças com deficiência ou sobredotados, crianças da rua ou crianças que trabalham, crianças de populações remotas ou nómadas, crianças de minorias linguísticas, étnicas ou culturais e crianças de áreas ou grupos desfavorecidos ou marginais (p. 6).

O mesmo será dizer que, ao contrário do modelo tradicional que exige, por parte do aluno, a sua adequação à norma vigente, é à escola do século $\mathrm{XXI}$ que cabe 'outrar-se', isto é, flexibilizar-se e adequar-se, indo ao encontro das características individuais dos alunos, das suas necessidades e potencialidades e fazendo da diferença uma mais-valia para o desenvolvimento de cada um, com benefícios claros para todos. A verdade é que a escola, na sua atitude de (mera) aceitação dos 'diferentes', tolerando a sua presença no mesmo espaço físico dos outros alunos, tem teimado em não chamar a si as atribuições causais do insucesso de alguns, querendo perpetuar a ideia da 'inadequação' do aluno 'diferente' ao sistema, cuja estrutura, de alguma forma, se mantém securizante e sem riscos para os que a ela se vão conseguindo ajustar. De tal forma o conceito de inclusão tem sido 'maltratado' que alguns autores, como Correia (2008), chegam a advogar que "é tempo de deixarmos de tratar a inclusão em termos de classes inclusivas, escolas inclusivas ou mesmo de alunos incluídos" (p. 11). Embora considerando que o facto de falar em inclusão é, por si só, um ato exclusivo, esse facto não nos pode impedir, neste momento, de combater a exclusão, não só com o discurso, mas também com mudança de culturas, de políticas e de práticas (Ainscow, 1999; Both, Ainscow, Black-Hawkins, Vaughan, \& Shaw, 2000; Rodrigues, 2003; Gardou, 2003; entre outros), fazendo desse processo o grande desafio da educação de hoje, como nos diz Sanches (2005):

A mudança geradora de uma educação inclusiva é um dos grandes desafios da educação de hoje porque imputa à escola a responsabilidade de deixar de excluir para incluir e de educar a diversidade dos seus públicos, numa perspectiva de sucesso de todos e de cada um, independentemente da sua cor, raça, cultura, religião, deficiência mental, psicológica ou física (p. 128). 
Educar, incluindo, passa pela reorganização do processo de ensinoaprendizagem, descentrando das problemáticas individuais, dos planos educativos individuais e dos apoios especializados para a qualidade do processo educativo (Leitão, 2007). A perspetiva de resposta individual, a dominante na maioria dos países (Mittler, 2000), e que tenta ocultar diferentes razões (culturais, sociais, entre outras), tem de ser substituída por uma resposta coletiva, obrigando a medidas mais estruturantes e mais abrangentes. A estratégia poderá passar por não ir atrás da deteção das dificuldades/défices, mas, proativamente, ir ao encontro das soluções que têm vindo a ajudar a resolver os problemas, os desafios que se colocam às comunidades, sociais e educativas, caracterizadas pela diversidade dos seus públicos, mobilizando, corresponsabilizando e fazendo interagir todos os intervenientes e os próprios contextos (Sanches, 2011b).

\section{O caminho para a construção de escolas verdadeiramente inclusivas}

\section{Diferenciação pedagógica: $\boldsymbol{A}$ inclusão em ação}

Diferenciar não significa necessariamente incluir. Como refere Rodrigues (2003), "a diferenciação ou flexibilização curricular encontra-se (...) há muito tempo presente nos nossos sistemas educativos, só que não necessariamente numa perspectiva inclusiva" (p. 92). A criação de turmas especiais (turmas de percursos alternativos e os Cursos de Educação e Formação, por exemplo) ou, como denuncia Rodrigues (2003), o sistema paralelo de educação especial, seja em escolas especiais ou em salas de apoio, extra sala de aula, são exemplos claros de tentativas de diferenciação curricular. Também Roldão (2003) destaca que a diferenciação curricular acabou por se estruturar "historicamente como uma solução curricular não inclusiva" (p. 156), o que vai ao encontro da organização de currículos diferentes para classes sociais e grupos de alunos diferentes. Ora, como aponta Rodrigues (2003):

a diferenciação que se procura na inclusão é a que tem lugar num meio em que não se separam os alunos com base em determinadas categorias, mas em que se educam os alunos em conjunto, procurando aproveitar o potencial educativo das suas diferenças, em suma, uma diferenciação na classe assumida como um grupo heterogéneo (p. 92). 
Para Heacox (2006), o "ensino diferenciado significa alterar o ritmo, o nível ou o género de instrução que o professor pratica, em resposta às necessidades, aos estilos e aos interesses dos alunos" (p. 10).

Diferenciar passa, então, por conceder a cada aluno, de acordo com as suas potencialidades, a oportunidade de ter um lugar que é o seu, bem 'desenhado' no espaço do aprender, uma voz que é audível por todos e uma participação que se vê com nitidez e contribui para o crescimento cognitivo e social, próprio e dos seus pares. Diferenciar, incluindo, passa por uma estratégia de organização de grupos ou pares de níveis de aprendizagem diversos, a trabalharem numa tarefa organizada para rendibilizar essa diversidade (Roldão, 2003); passa por tirar partido das diversidades (experiências, culturas ou outras) para aprendizagens destinadas a toda a turma; passa, ainda, por potenciar e desenvolver o que cada um pode 'pôr ao serviço' do outro, para atingir um objetivo coletivo.

\section{Aprender cooperativamente: Eu ajudo-te, tu explicas-me, nós aprendemos}

A aprendizagem cooperativa tem sido descrita pela comunidade científica como a forma mais eficaz para colocar em ação uma efetiva diferenciação na sala de aula. Sprinthall e Sprinthall (1993) definem-na, não como uma única técnica, mas uma "mistura" de "técnicas de trabalho em pequenos grupos com objectivos de cooperação" (p. 311). Os mesmos autores explicam que a tónica deve ser colocada na interdependência entre os membros da aula atribuindo notas e reforços aos desempenhos do grupo, na medida em que a meta individual só pode ser alcançada quando todos os indivíduos do grupo alcancem as metas. Como afirma Deutch (s/d, cit. por Sprinthall \& Sprinthall, 1993):

A probabilidade de recompensa está positivamente associada de forma que, à medida que a situação pessoal de cada um melhora ou piora, o mesmo acontece em relação aos outros... a ponto de se eu ganhar, tu ganhas e se eu perder, tu perdes (p. 516).

Sanches (2005, p. 136), citando Meijer (2003), apresenta como ingredientes importantes para a implementação de abordagens cooperativas à aprendizagem "objetivos bem determinados, métodos de ensino/aprendizagem alternativos, um ensino flexível e a constituição de 
subgrupos" - na sua opinião, os meios mais eficazes "para gerir a diferença e ajudar a aprender os mais e os menos capazes". Estes e outros autores defendem, assim, que tais procedimentos encorajam a participação de todos os alunos e têm como resultado um melhor desempenho académico. Para além dos ganhos cognitivos para todos, sublinha-se que "quanto mais cooperativas forem as tarefas em grupo, mais positivo será o ambiente geral da sala de aula" e que as mesmas "conduzem a níveis mais altos de motivação intrínseca, especialmente entre as crianças menos capazes" (Sprinthall \& Sprinthall, 1993, p. 516). Outro aspeto relevante prende-se com os ganhos, a nível social, possibilitados pelo aumento das interações entre os pares na sala de aula, levando os alunos, com a ajuda do professor, enquanto mediador, a aplicar os princípios da aceitação e do respeito mútuo.

A aprendizagem cooperativa, bem defendida em termos discursivos, como prova o grande número de registos presentes no acervo científico educacional (Freinet, 1975; Johnson, Johnson, Johnson, \& Anderson, 1976; Slavin, 1991; Bessa \& Fontaine, 2002a; Freitas \& Freitas, 2002; Fontes \& Freixo, 2004; Sanches, 2005; Leitão, 2006; Lopes \& Silva, 2009; entre outros), não o é por todos os que defendem uma sociedade neoliberal, com uma escola vocacionada para a seleção dos melhores, onde o individualismo e a competição são "princípios muito enraizados". O nosso sistema educativo e seus agentes, privilegiando um sistema de avaliação centrado na norma, visando diferenciar os indivíduos entre si e fazendo, por vezes, com que o sucesso de uns dependa do insucesso dos restantes, insurge-se contra a aprendizagem cooperativa, apelidando-a de facilitista, indiferenciadora e geradora de ignorantes, o que não tem sido confirmado nas largas investigações feitas sobre esta temática (cf. autores suprarreferenciados).

\section{Professores cooperativos: Refletir, partilhar e criar}

Para que o professor seja de facto um mediador das aprendizagens e interações no grupo, terá necessariamente de corresponder a um novo modelo de professor e um novo modelo de 'comunidade de professores', principais agentes da mudança em contexto educativo. A este propósito, Leitão (2007) afirma saber-se que as escolas em que os professores trabalham em parceria pedagógica, na sala de aula, são aquelas em que se verificam maiores mudanças, que proporcionam melhores condições de 
aprendizagem e que mais facilitam a inclusão das crianças e dos jovens com deficiência. Também Toledo e Vitaliano (2010) concluem da sua investigação sobre a formação de professores, usando um modelo colaborativo (professor do ensino regular e professor de educação especial), que o trabalho colaborativo desenvolvido entre ambos, incluindo a sala de aula, favorece o processo de inclusão de alunos com deficiência intelectual.

Nesta perspetiva de mudança, Morgado (2005, p. 47) defende as ideias de Stenhouse (1987), colocando a tónica no "ensino como prática reflexiva" e na "classe docente como colectivo profissional reflexivo", devendo os professores assumir-se como "agentes activos de investigação da sua própria prática". O autor advoga que, para que tal aconteça, é "necessário fazer das práticas docentes lugares estratégicos de investigação", onde a reflexão sobre a sua ação adquire um papel preponderante (p. 46). Nesta medida, cada situação-problema emergida do seu quotidiano concreto poderá ser sentida, pelo professor, como um desafio e despoletar a sua capacidade autocrítica e reflexiva, num desejo de se superar, encarando as situações problemáticas como oportunidades de inovação pedagógica.

O abandono da postura do professor solitário, pela partilha das suas experiências com outros docentes, constituindo equipas cooperativas de trabalho, que abram espaço a uma reflexão/experimentação conjuntas, afigura-se como a mudança mais premente no seio das nossas escolas e que mais eco terá nas salas de aula. Pelo exposto, concordamos com Sanches (2001) quando refere que "a escola inclusiva somos todos nós e cada um a cooperar para uma escola mais justa, mais humana, em que cada um tem um espaço e um tempo que são seus para usufruir e partilhar" (p. 93).

\section{Enquadramento metodológico}

Para a consecução dos nossos objetivos de investigação, utilizámos a abordagem qualitativa, consubstanciada numa investigação-ação, processo desencadeado a partir de um problema real, experienciado e identificado como tal, sobre o qual interviemos com vista a gerar mudanças e melhorar a realidade observada.

O projeto em causa desenvolveu-se ao longo das três fases apresentadas no Quadro I. 


\section{Quadro I - Fases do projeto, objetivos e procedimentos}

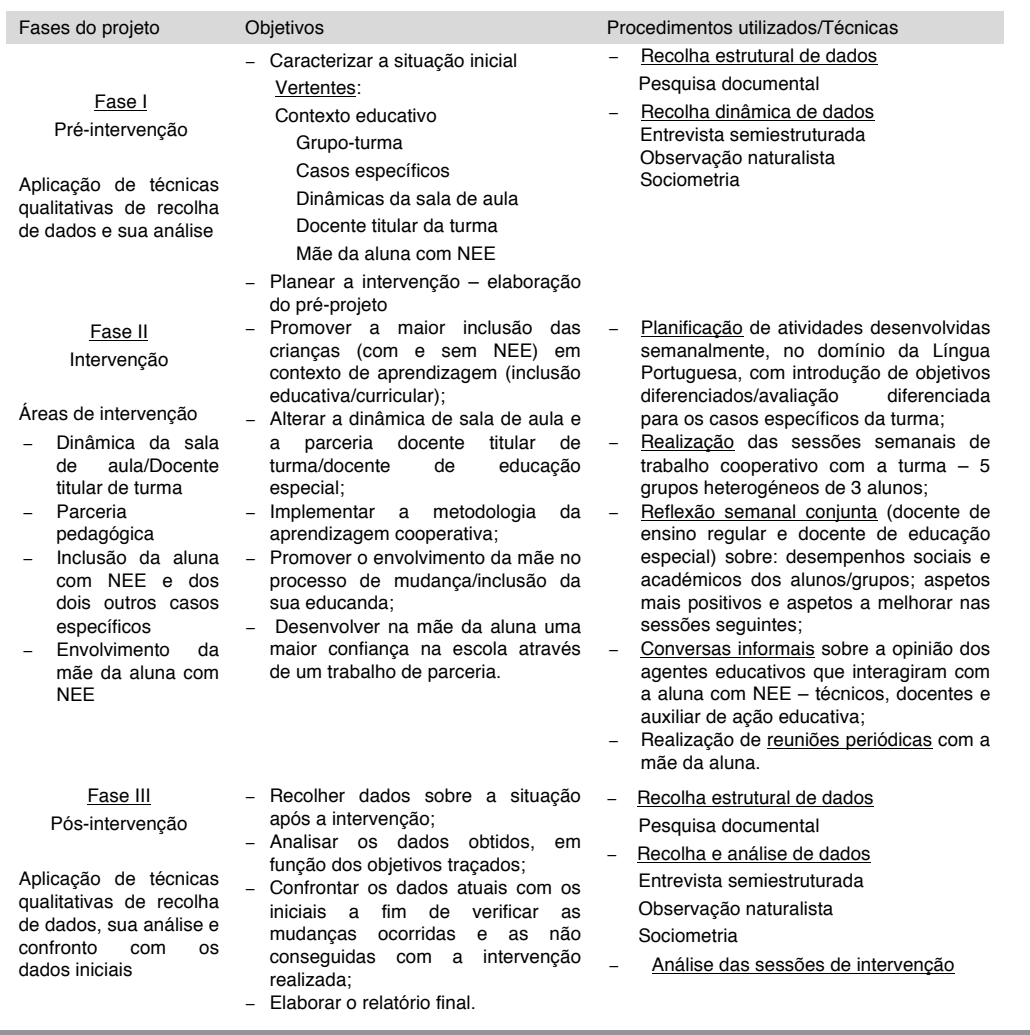

\section{Fase I - Pré-intervenção}

$\mathrm{Na}$ primeira fase, inserimo-nos no contexto educativo que selecionámos a fim de o caracterizar para tomar decisões quanto às ações a desenvolver no sentido da mudança. Para tal, foram recolhidos dados de caráter estrutural, através da pesquisa documental, e dados de caráter dinâmico, com aplicação das técnicas qualitativas de investigação apresentadas: entrevista semiestruturada à docente titular da turma; questionário sociométrico aos alunos da turma; e observação naturalista não participante, num momento de leitura e interpretação de texto (dois textos diferentes/dois anos de escolaridade diferentes). Procedemos à análise compreensiva da situação e ao cruzamento de todos os dados obtidos, 
utilizando a análise de conteúdo, nos casos da entrevista e da observação naturalista, e, no caso da sociometria, a elaboração de matrizes sociométricas (escolhas/rejeições/reciprocidades nas escolhas e nas rejeições dos alunos, em diferentes situações de interação). Tal análise possibilitou-nos caracterizar, quer o contexto educativo, quer o grupo-turma e os casos específicos pertencentes ao mesmo, nomeadamente a criança com NEE nele inserida, quer ainda as dinâmicas daquela sala de aula e o perfil da docente relativamente aos aspetos relacionados com a inclusão em geral e a desta aluna em particular.

Assim, partimos do contexto educativo de uma turma de quinze alunos (doze rapazes e três raparigas), de $2^{\circ}$ e $3^{\circ}$ anos de escolaridade, com idades compreendidas entre os seis e os oito anos. Sete alunos encontravam-se matriculados no $2^{\circ}$ ano (duas raparigas e cinco rapazes) e oito alunos pertenciam ao $3^{\circ}$ ano (uma rapariga e sete rapazes). Uma aluna do terceiro ano, a $M A^{1}$, apresentava uma retenção, no $2^{\circ}$ ano de escolaridade, tratandose de uma criança considerada com necessidades educativas especiais de caráter permanente, de natureza física e cognitiva, abrangida pelo decreto-lei n. ${ }^{\circ} 3 / 2008$, de 7 de janeiro ${ }^{2}$, tendo como professora de educação especial uma das autoras deste artigo e do trabalho de projeto.

As informações recolhidas no Projeto Curricular da Turma permitiramnos afirmar que, a nível do comportamento em contexto de sala de aula, se tratava de uma turma "globalmente satisfatória". Quanto às competências académicas, foi possível apurar que os alunos do $2^{\circ}$ ano tinham adquirido os conteúdos do $1^{\circ}$ ano, em todas as áreas curriculares; relativamente aos alunos do $3^{\circ}$ ano, constatámos que cinco dos oito alunos apresentavam "bastantes dificuldades de compreensão e aplicação de conhecimentos", sobretudo nas áreas curriculares de Língua Portuguesa e Matemática, evidenciando "problemas ao nível da compreensão e expressão sobretudo escritas, raciocínio lógico e cálculo aritmético". Dois alunos do $3^{\circ}$ ano destacavam-se de todo o grupo-turma por apresentarem resultados "bastante mais abaixo do que o esperado" para o ano de escolaridade anterior ( $2^{\circ}$ ano), um deles a MA.

De acordo com os dados da primeira entrevista realizada à docente titular de turma, corroborados pelos dados da pesquisa documental, os alunos do $2^{\circ}$ ano foram referenciados como sendo um grupo com um bom nível de 
aproveitamento em todas as áreas académicas: "o $2^{\circ}$ ano é um grupo bom, dinâmico, trabalhador... empenhado". Pelo contrário, os do $3^{\circ}$, na opinião da professora, apresentavam fraco rendimento, também em todas as áreas: "o $3^{\circ}$ ano deixa muito a desejar... porque eles têm imensas dificuldades".

Quanto ao comportamento, as unidades de registo apontam sobretudo para a boa qualidade dos relacionamentos entre os alunos. Foi possível confirmar estes dados, quer pela observação naturalista, quer pelos dados obtidos nas matrizes sociométricas. Todos os alunos foram escolhidos pelos colegas; verificou-se um número elevado de reciprocidades nas escolhas; oito alunos foram rejeitados; houve reciprocidade nas rejeições. De salientar que, embora a docente da turma se referisse sempre a dois grupos distintos dentro da turma, essa divisão não se encontrou presente nas suas relações e escolhas, sendo totalmente irrelevante o critério de ano nas escolhas/rejeições por eles registadas no questionário sociométrico. Pelos dados obtidos na observação realizada, foi possível compreender também, a este respeito, que, embora a turma apresentasse uma boa qualidade dos relacionamentos interpessoais, esta potencialidade do grupo não estava a ser maximizada ou devidamente canalizada para as situações de aprendizagem em contexto de sala de aula, tendo em conta que foi o diálogo vertical aquele que dominou por completo as interações no espaço pedagógico.

$\mathrm{Na}$ segunda fase, encontradas as 'fragilidades' passíveis de serem intervencionadas, traçámos um Plano de Ação em diversas áreas, para alcançar uma 'situação mais desejável' do ponto de vista pedagógico e inclusivo, de acordo com os objetivos de investigação inicialmente traçados. A tomada de decisões concretizada no referido Plano esteve na base da intervenção realizada durante o período que decorreu entre fevereiro e junho de 2010. Interviemos não só com a turma, através de sessões semanais de trabalho cooperativo na área da Língua Portuguesa, mas também com a docente titular, planificando as atividades e refletindo em conjunto, e ainda com a mãe da aluna considerada com NEE, através de reuniões periódicas.

Tratando-se a investigação-ação de um processo dinâmico e contínuo de 'ação-reflexão-ação', a condução da nossa intervenção, apesar de previamente estruturada, integrou, no seu decurso, reflexões sistemáticas sobre as ações em desenvolvimento e suas repercussões a curto prazo, semanalmente (cf. Quadros II e III, exemplificação de uma das 16 sessões, 
todas elas registadas e documentadas). Estes procedimentos implicaram reajustamentos em relação ao planeamento inicial (planeamento global da intervenção), tendo este funcionado como uma matriz de caráter flexível, com alteração de alguns aspetos à medida que se verificou a necessidade de integrar novos dados colhidos do próprio processo de intervenção.

A terceira fase do nosso projeto consistiu em nova recolha de dados, com aplicação das mesmas técnicas de recolha utilizadas no período de préintervenção, com vista a verificar as mudanças operadas, nas diferentes áreas de intervenção, e a redação do respetivo relatório. Os procedimentos utilizados para a análise dos dados de recolha dinâmica seguiram as mesmas metodologias (análise de conteúdo e elaboração e análise de matrizes sociométricas).

\section{Fase II - Intervenção}

Depois de uma planificação global, devidamente fundamentada em toda a investigação empírica, cotejada com a informação teórica, partimos para a intervenção em sala de aula, que decorreu nos $2^{\circ}$ e $3^{\circ}$ períodos de 2010, entre fevereiro e junho, com a realização de sessões semanais, exemplificadas nos Quadros II e III, 16 no total. Cada atividade pedagógica variou, na sua duração, entre 90 minutos e duas manhãs, em função da natureza da atividade em causa e do grau de complexidade e exigência da mesma. Antes da concretização das atividades foram elaboradas as respetivas planificações e preparados os materiais necessários à sua realização. Cada uma das planificações elaboradas contemplou, para além de aspetos mais genéricos como data, número da(s) sessão/sessões, área curricular, metodologia utilizada, objetivos gerais e específicos e recursos materiais, um resumo da atividade e ainda um roteiro detalhado com todos os passos da sessão, desde o seu início até ao final. Tendo em conta que os recursos humanos, para além dos alunos, foram sempre as duas docentes em cooperação na sala de aula, não verificámos a necessidade de explicitar tal informação em cada planificação.

Após a concretização de cada atividade, foi feito um balanço com os alunos. Posteriormente, as duas docentes trocaram impressões, refletindo em conjunto, aspetos que surgem expressos em cada quadro que se apresenta a 
seguir a cada planificação e que se refere à avaliação e reflexões sobre a atividade em causa. Nesta avaliação, procurámos apresentar uma reflexão o mais abrangente possível acerca de todos os aspetos que são colocados em ação quando se trata de realizar uma atividade pedagógica: desde as questões relacionadas com alterações necessárias à planificação até à forma como os alunos acolheram a atividade, participaram e a desempenharam, as interações sociais que dela emergiram, situações imprevistas e soluções encontradas pelas docentes. Foram ainda apresentadas reflexões sobre os aspetos positivos que mais ressaltaram de cada atividade, bem como aquelas questões que, em nosso entender e pelo balanço feito, necessitavam de ser melhoradas. Apresentamos de seguida o exemplo de duas das 16 sessões realizadas, nas suas várias componentes (Quadros II e III). 


\section{Quadro II - Planificação das sessões n' 10 e 11}

\begin{tabular}{|c|c|c|}
\hline \multicolumn{3}{|c|}{ sões n ${ }^{\circ} 10$ e 11 - Atividade "Histórias com asas" } \\
\hline Área curricular: Língua Portuguesa & & Datas: 04.05.2010; 05.05.2010 \\
\hline & & $\underline{\text { Tempo previsto: duas manhãs }}$ \\
\hline \multicolumn{2}{|c|}{$\begin{array}{l}\text { Resumo da atividade: } \\
\text { - Fase I (Sessão 10): Os alunos leem e resumem os } \\
\text { acontecimentos que ocorrem nos capítulos da história já } \\
\text { construídos por outras turmas; } \\
\text { - Fase II (Sessão 11): Depois de assimilada a informação essencial } \\
\text { - sequência da história, personagens, tempo, espaço, etc. -, dão } \\
\text { continuidade ao capítulo IX, elaborando um texto que constituirá o } \\
\text { final da história (capítulo X) coletiva interturmas. }\end{array}$} & \\
\hline \multicolumn{2}{|c|}{ Competências sociais } & Cor \\
\hline \multicolumn{2}{|c|}{$\begin{array}{l}\text { Objetivo geral: Aprender a cooperar em grupo. } \\
\text { Objetivos específicos: } \\
\text { - Escutar o outro com atenção sem o interromper; } \\
\text { - Ajudar os colegas, quando necessário; } \\
\text { - Pedir ajuda quando necessita; } \\
\text { - Respeitar ideias diferentes das suas; } \\
\text { - Avaliar atitudes próprias e o funcionamento do seu grupo (reflexão } \\
\text { sobre os aspetos positivos e o que há a melhorar). } \\
\text { Objetivos diferenciados } \\
\text { MA } \\
\text { - Discordar de forma assertiva. } \\
\text { RR } \\
\text { - Aumentar a sua participação na atividade, no seio do novo grupo. }\end{array}$} & $\begin{array}{l}\text { Objetivo geral: Desenvolver a compreensão e } \\
\text { a expressão orais e escritas. } \\
\text { Objetivos específicos: } \\
\text { - Identificar, registando na folha, todas as } \\
\text { personagens que surgem no Capítulo I; } \\
\text { - Recontar a história retratada nesse Capítulo; } \\
\text { - Dar ideias para a construção da } \\
\text { história/Capítulo X. } \\
\text { Objetivos diferenciados (MA e RR): } \\
\text { - Reter as personagens principais da história; } \\
\text { - Verbalizar um acontecimento da história; } \\
\text { - Dar uma ideia para a construção da história. }\end{array}$ \\
\hline \multicolumn{3}{|c|}{$\begin{array}{l}\text { Avaliação: observação direta dos comportamentos e desempenhos dos alunos; questões a cada grupo sobre o } \\
\text { capítulo da história que lhes coube ler; sugestões dadas, por cada grupo, para a história; atribuição de nota qualitativa } \\
\text { a todos os alunos e seu registo em grelha própria; reflexão conjunta entre alunos e docentes. }\end{array}$} \\
\hline \multicolumn{3}{|c|}{$\begin{array}{l}\text { De acordo com a reflexão feita a propósito da sessão anterior, a constituição dos grupos passou a ser a seguinte: } \\
\qquad \begin{array}{l}1 \text { - MA DL NC (reestruturado) } \\
2 \text { - AP RR DS } \\
\text { 3 - JM CS MN } \\
4 \text { - MM JH GM (reestruturado) } \\
5 \text { - AM MF VF (reestruturado) }\end{array}\end{array}$} \\
\hline \multicolumn{3}{|c|}{$\begin{array}{l}1 \text { - Solicitação aos alunos que verbalizem os objetivos do trabalho cooperativo (os alunos já sabem o que se espera } \\
\text { deles, em termos de trabalho cooperativo); } \\
2 \text { - Explicação da atividade, do que vai ser avaliado (objetivos específicos da atividade) e do tempo de que dispõem, } \\
\text { em cada momento da atividade; } \\
3 \text { - "Negociação" do papel de cada elemento no grupo, pelos próprios alunos (controlador do tempo / controlador do } \\
\text { volume / moderador / porta-voz), variando novamente nessa distribuição relativamente aos papéis assumidos } \\
\text { anteriormente; } \\
4 \text { - Realização da atividade: i- as docentes leem o Capítulo I (o maior) e os alunos, previamente instruídos para tal, } \\
\text { registam os nomes das personagens da história enquanto a ouvem; ii- em grande grupo, os alunos são questionados } \\
\text { sobre o conteúdo desse capítulo e sobre as personagens que interagem na história, para verificar a sua } \\
\text { compreensão; iii- cada grupo recebe um ou dois capítulos, em função da extensão de cada texto e das capacidades } \\
\text { dos grupos; iv- dentro de cada grupo, os alunos leem o(s) capítulo(s) que Ihes couber(am) e resumem entre si a } \\
\text { informação, contando os acontecimentos uns aos outros; v- cada porta-voz conta aos restantes grupos o conteúdo do } \\
\text { seu texto, com a ajuda dos restantes colegas do grupo; vi- no final da intervenção de cada porta-voz, as docentes } \\
\text { colocam questões a todos os alunos sobre o que ouviram. } \\
\text { Sessão } 11\end{array}$} \\
\hline
\end{tabular}




\section{Quadro III - Avaliação e reflexões sobre a atividade das sessões $n^{\circ} 10$ e 11}

\begin{tabular}{|c|c|}
\hline Balanço geral & $\begin{array}{l}\text { Cumprimento da planificação / Eventuais alterações na concretização da atividade / Outros aspetos relevantes } \\
\text { A atividade decorreu conforme o plano previsto. Relativamente às datas de concretização da atividade, verificou-se a necessidade } \\
\text { de dar continuidade à atividade logo no dia seguinte, a fim de assegurar que os alunos não iriam esquecer a história (capítulos já } \\
\text { elaborados); por este motivo, e visto que a docente de educação especial não poderia estar presente no dia em causa por } \\
\text { questões de horário noutras escolas, a sessão } 11 \text { foi inteiramente realizada apenas pela docente de ensino regular. Assim, a } \\
\text { avaliação da sessão ficou a cargo da mesma docente, que anotou a sua avaliação dos grupos e dos casos especificos e depois a } \\
\text { transmitiu à colega de educação especial. } \\
\text { Foram postas em prática as alterações na constituição dos grupos } 1,4 \text { e } 5 \text {, decorrentes dos aspetos refletidos na sessão anterior. } \\
\text { A leitura dos resultados desta estratégia permite fazer dela um balanço positivo. }\end{array}$ \\
\hline $\begin{array}{c}\text { Avaliação dos } \\
\text { desempenhos } \\
\text { dos alunos } \\
\text { (dados obtidos } \\
\text { da observação } \\
\text { direta) }\end{array}$ & 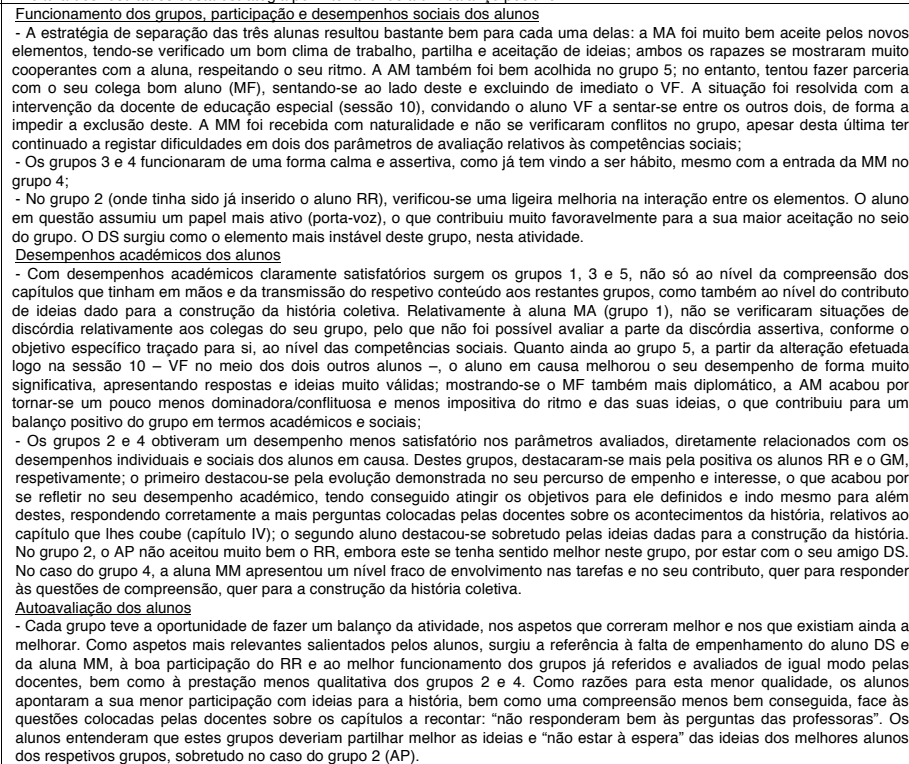 \\
\hline $\begin{array}{l}\text { Reflexão- } \\
\text { síntese: Aspetos } \\
\text { positivos e a } \\
\text { melhorar }\end{array}$ & $\begin{array}{l}\text { Aspetos positivos mais relevantes } \\
\text { - O facto de a concretização da sessão } 11 \text { ter ficado a cargo da docente titular de turma, bem como a avaliação dos alunos e da } \\
\text { atividade no final, permitiu-lhe ganhar mais agilidade na gestão do trabalho com esta metodologia específica, estando sozinha na } \\
\text { sala de aula, e no estar mais atenta aos 'sinais' em termos de atitudes/comportamentos sociais dos alunos e suas evoluções. Por } \\
\text { outro lado, o facto de a docente ter necessitado de registar as suas reflexões para posteriormente as poder transmitir à docente de } \\
\text { educação especial revelou-se um aspeto gratificante e, ao mesmo tempo, revelador de mudança, pois permitiu que emergisse o } \\
\text { que se pretende, em termos da atitude do docente face à sua atividade profissional - tornar-se mais reflexiva sobre as suas } \\
\text { práticas, apontar sugestões de melhoria, avaliar em função de objetivos estipulados a curto prazo e promover essa mesma } \\
\text { capacidade reflexiva nos alunos sobre os aspetos positivos e os que devem ser melhorados. Referiu que os grupos participaram } \\
\text { de forma bastante ativa na sessão } 11 \text {, destacou com desempenhos académicos positivos os alunos: RR, JM, MF e AM; } \\
\text { - A maior estabilização do papel de cada aluno dentro do grupo e a sua capacidade em mantê-lo até ao final da atividade. Para } \\
\text { este aspeto, terá contribuido o facto de os alunos terem vindo a verificar que os seus papéis dentro do grupo vão variando, } \\
\text { diminuindo assim também uma certa conflitualidade inicial na 'guerra' sobre 'quem faz o quê' durante a realização das tarefas em } \\
\text { cada sessão; } \\
\text { - A evolução do aluno RR no seio do novo grupo; } \\
\text { - A participação ativa da MA, o seu notório empenhamento, trabalho em equipa e maior capacidade de se expor, sem receio, } \\
\text { perante o grande grupo; } \\
\text { Aspetos a melhorar } \\
\text { - Envolver mais a aluna MM nas tarefas de grupo de forma a que assuma uma postura mais ativa; } \\
\text { - Atribuir um papel mais preponderante ao aluno DS para que se mantenha mais 'preso' às atividades; } \\
\text { - Promover de forma mais ativa o espirito de entreajuda e a interdependência positiva nos alunos AM e AP. }\end{array}$ \\
\hline
\end{tabular}




\section{Fase III - Pós-intervenção}

\section{Os resultados: $O$ antes e o depois}

Foram diversas as preocupações de investigação iniciais que nos lançaram neste processo de mudança: a questão das metodologias utilizadas na sala de aula e o seu real contributo para uma aprendizagem com significado para os alunos e para uma efetiva inclusão educativa da MA, social e académica; a forma como a docente titular perspetivava o apoio a prestar a esta aluna pela docente de educação especial; a maneira como os alunos interagiam nas situações de aprendizagem; e ainda o modo como a encarregada de educação da MA se posicionava face à escola e à problemática da sua educanda. Todos estes aspetos nos conduziram à problematização da situação inicial, a qual norteou os objetivos do nosso trabalho. Assim, partimos da questão que para nós se afigurou como central: se, através do nosso projeto de investigação-ação, poderíamos tornar aquela sala de aula mais inclusiva e estimulante para a MA e para todos os alunos, aumentando as interações entre si através da criação de situações de aprendizagem baseadas na cooperação e na diferenciação positiva.

Era nosso propósito: promover a socialização de saberes académicos na turma, através de estratégias de diferenciação pedagógica inclusiva, baseadas no trabalho cooperativo; promover uma maior inclusão da MA através do desenvolvimento de competências pessoais, sociais e académicas no seio da turma; alterar as dinâmicas da sala de aula; desenvolver uma parceria pedagógica com a docente titular de turma; desenvolver uma capacidade autocrítica e autorreflexiva em nós e na docente; e, ainda, aumentar a confiança da encarregada de educação da MA nos agentes educativos e a aceitação das características cognitivas da mesma.

Neste sentido, e com o intuito de avaliar o alcance dos objetivos acima referidos, os resultados que a seguir se apresentam incidem em três eixos do Plano de Ação traçado: 1) intervenção focalizada nos alunos; 2) intervenção focalizada na parceria pedagógica entre as docentes e na dinâmica de sala de aula; 3) intervenção focalizada na mãe da MA. De salientar ainda que os resultados obtidos decorrem dos dados recolhidos no final da intervenção (junho e julho de 2010), através de nova aplicação do questionário sociométrico aos alunos e elaboração e análise das respetivas matrizes sociométricas, da realização de nova entrevista à docente titular de turma, de uma segunda 
observação naturalista em contexto de aula e ainda da informação contida nas atas das reuniões realizadas com a mãe da MA. Também as avaliações e reflexões feitas ao longo da intervenção nos forneceram informação importante para sustentar os resultados que a seguir se apresentam.

\section{Intervenção focalizada nos alunos}

Os dados obtidos pelas técnicas utilizadas, após a intervenção, apontam para resultados significativos ao nível dos desempenhos sociais e académicos dos alunos, do seu envolvimento nas atividades, quer dos alunos em geral, quer dos casos particulares, uns identificados no início pela docente titular de turma, outros identificados como tal ao longo do processo de intervenção. Para além dos dados evidenciados nas avaliações e reflexões sobre cada sessão (devidamente registados), são expressos, aqui, os dados mais significativos da recolha dinâmica, quer pela entrevista, quer pela observação naturalista, cuja síntese se apresenta nos quadros IV e V.

\section{Quadro IV - Desempenhos sociais e académicos dos alunos - Síntese dos dados obtidos na $2^{\mathrm{a}}$ entrevista à professora}

\begin{tabular}{|c|c|c|c|}
\hline $\begin{array}{l}\text { Categorias / } \\
\text { Total de } \\
\text { unidades de } \\
\text { registo }\end{array}$ & $\begin{array}{l}\text { Subcategorias / } \\
\text { Total de unidades } \\
\text { de registo }\end{array}$ & $\begin{array}{l}\text { Sub- } \\
\text { subcategorias / } \\
\text { Total de } \\
\text { unidades de } \\
\text { registo }\end{array}$ & Dados relevantes \\
\hline \multirow{3}{*}{$\begin{array}{l}\text { Balanço do } \\
\text { percurso } \\
\text { dos alunos } \\
\text { com a } \\
\text { intervenção } \\
\text { realizada } \\
(76)\end{array}$} & \multirow[b]{2}{*}{$\begin{array}{l}\text { Aspetos positivos } \\
\text { salientados } \\
\quad(50)\end{array}$} & $\begin{array}{l}\text { Desempenhos } \\
\text { sociais dos } \\
\text { alunos } \\
\text { (28) }\end{array}$ & $\begin{array}{l}\text { - Experiência positiva para todos os alunos - aprenderam a } \\
\text { trabalhar em grupo, a partilhar ideias, a respeitar e a } \\
\text { ceder; } \\
\text { - Ganharam consciência das suas dificuldades em } \\
\text { trabalhar em grupo, principalmente os bons alunos. }\end{array}$ \\
\hline & & $\begin{array}{l}\text { Desempenhos } \\
\text { académicos } \\
\text { (22) }\end{array}$ & $\begin{array}{l}\text { - A experiência ajudou os alunos }\left(2^{\circ} \text { e } 3^{\circ} \text { anos) na Língua }\right. \\
\text { Portuguesa (construção de textos); } \\
\text { - O } 3^{\circ} \text { ano aproximou-se mais do } 2^{\circ} \text { (o grupo melhor no } \\
\text { início da intervenção); } \\
\text { - O } 3^{\circ} \text { ano melhorou as suas competências em Língua } \\
\text { Portuguesa; } \\
\text { - Alunos mais desconcentrados e com potencialidades } \\
\text { melhoraram o seu desempenho; } \\
\text { - Desempenhos satisfatórios no caso dos alunos mais } \\
\text { fracos. }\end{array}$ \\
\hline & $\begin{array}{l}\text { Aspetos menos } \\
\text { positivos } \\
(26) \\
\end{array}$ & ---- & $\begin{array}{l}\text { - As dificuldades de alguns bons alunos (ex.: AM) em } \\
\text { aceitar as dificuldades dos menos bons cognitivamente; } \\
\text { - A dispersão do RR e do DS nas sessões. }\end{array}$ \\
\hline \multirow{3}{*}{$\begin{array}{l}\text { Percurso da } \\
\text { MA (71) }\end{array}$} & $\begin{array}{c}\text { Progressos } \\
\text { verificados ao nível } \\
\text { emocional/relacional } \\
(25) \\
\end{array}$ & ---- & $\begin{array}{l}\text { - Mais segurança; } \\
\text { - Mais amizades. }\end{array}$ \\
\hline & $\begin{array}{l}\text { Inclusão educativa } \\
\text { (32) }\end{array}$ & -------- & $\begin{array}{l}\text { - A aluna passou a ser vista como uma igual aos outros } \\
\text { dentro da turma, capaz de participar e realizar tarefas } \\
\text { como os outros. }\end{array}$ \\
\hline & $\begin{array}{l}\text { Progressos ao nível } \\
\text { académico (Língua } \\
\text { Portuguesa) } \\
\text { (14) }\end{array}$ & & $\begin{array}{l}\text { - Evolução positiva, apesar das dificuldades cognitivas de } \\
\text { caráter permanente; } \\
\text { - Melhoria na avaliação final de Língua Portuguesa. }\end{array}$ \\
\hline
\end{tabular}




\section{Quadro V - Interações horizontais e envolvimento na atividade - Síntese dos dados obtidos na $2^{\mathrm{a}}$ observação naturalista}

\begin{tabular}{|c|c|c|c|}
\hline $\begin{array}{l}\text { Categorias / } \\
\text { Total de } \\
\text { unidades de } \\
\text { registo }\end{array}$ & $\begin{array}{l}\text { Subcategorias / } \\
\text { Total de } \\
\text { unidades de } \\
\text { registo }\end{array}$ & $\begin{array}{c}\text { Sub- } \\
\text { subcategorias / } \\
\text { Total de unidades } \\
\text { de registo }\end{array}$ & Dados relevantes \\
\hline \multirow{3}{*}{$\begin{array}{l}\text { Interações } \\
\text { horizontais nos } \\
\text { grupos } \\
(41)\end{array}$} & $\begin{array}{c}\text { Interações } \\
\text { horizontais dos } \\
\text { alunos em geral } \\
(23)\end{array}$ & & $\begin{array}{l}\text { - Verifica-se a existência de uma quantidade significativa } \\
\text { de interações horizontais e a sua qualidade - interações } \\
\text { positivas, trabalho coordenado entre os elementos dos } \\
\text { grupos, boa cooperação e partilha de ideias. }\end{array}$ \\
\hline & $\begin{array}{c}\text { Interações } \\
\text { horizontais para } \\
\text { com os casos } \\
\text { particulares } \\
(12)\end{array}$ & & $\begin{array}{l}\text { - Os alunos demonstram uma atitude cooperativa e } \\
\text { espírito de entreajuda para com os alunos assinalados } \\
\text { com casos particulares. }\end{array}$ \\
\hline & $\begin{array}{l}\text { Aspetos menos } \\
\text { positivos } \\
\quad(6)\end{array}$ & & $\begin{array}{l}\text { - Situações pontuais relacionadas com os alunos DS, } \\
\text { AM e NC; } \\
\text { - Alguns grupos não se lembraram dos papéis } \\
\text { estipulados para cada um, dentro de cada grupo. }\end{array}$ \\
\hline \multirow{5}{*}{$\begin{array}{l}\text { Envolvimento } \\
\text { dos alunos na } \\
\text { atividade } \\
\quad(68)\end{array}$} & $\begin{array}{c}\text { Alunos em geral } \\
(28)\end{array}$ & & $\begin{array}{l}\text { - Grande envolvimento por parte de todos os alunos da } \\
\text { turma, revelando interesse, motivação e entusiasmo. }\end{array}$ \\
\hline & \multirow{4}{*}{$\begin{array}{l}\text { Casos } \\
\text { particulares } \\
\quad(40)\end{array}$} & $\begin{array}{l}\text { MA } \\
(13)\end{array}$ & $\begin{array}{l}\text { - "Elevado" nível de empenho e participação bastante } \\
\text { ativa; } \\
\text { - Motivação, segurança e iniciativa na realização das } \\
\text { atividades. }\end{array}$ \\
\hline & & $\begin{array}{l}\text { DS } \\
(9)\end{array}$ & $\begin{array}{l}\text { - "Elevado" nível de empenho; } \\
\text { - Demonstração de entusiasmo. }\end{array}$ \\
\hline & & $\begin{array}{l}\text { VF } \\
(9)\end{array}$ & $\begin{array}{l}\text { - Empenho, participação ativa e satisfação na realização } \\
\text { das atividades. }\end{array}$ \\
\hline & & $\begin{array}{l}\mathrm{RR} \\
(9)\end{array}$ & $\begin{array}{l}\text { - Unidades de registo de atenção, motivação e empenho } \\
\text { na atividade; } \\
\text { - Colaboração com os pares do seu grupo. }\end{array}$ \\
\hline
\end{tabular}

Comparando os dados obtidos após a intervenção com a recolha inicialmente realizada, podemos reafirmar que a situação caracterizada apontava para necessidades de mudança ao nível das interações horizontais em situações de aprendizagem, passando a aproveitar melhor o seu bom potencial relacional, revelado nas primeiras matrizes sociométricas, aliado à questão da separação considerada como não benéfica dos dois grupos dentro da mesma sala de aula ( $2^{\circ}$ e $3^{\circ}$ anos) e ao 'desequilíbrio' académico entre os dois anos de escolaridade e cujo trabalho em separado pouco parecia contribuir para a melhoria da qualidade das suas aprendizagens.

Pela intervenção realizada, com a organização dos alunos em grupos heterogéneos em termos cognitivos e não separados por ano de escolaridade, conforme se pode verificar quer pelas sessões realizadas, quer pelos dados da segunda observação naturalista, conseguimos colocar os alunos em diálogo horizontal permanente nas situações de aprendizagem, trocando 'experiências curriculares' na área da Língua Portuguesa. Este aspeto é bem visível ao compararmos os dados da primeira observação - 15 unidades de comportamento da categoria Interações horizontais apontam 
para a ausência dessas mesmas interações - com as 41 unidades que constituem a categoria Interações horizontais nos grupos, os quais evidenciam, não só uma cooperação entre os elementos de cada grupo, mas também uma "interação intergrupos". Destas 41 unidades, 12 referem-se à subcategoria Interações horizontais para com os casos particulares, assinalando o espírito de entreajuda e cooperação dos alunos com melhor rendimento escolar em relação aos quatro colegas considerados como casos particulares e alvo de diferenciação nos objetivos ao longo da intervenção.

No que se refere ainda aos resultados do ponto de vista social, pudemos constatar, pela segunda observação e pela segunda entrevista, e ainda pelas grelhas de avaliação dos desempenhos dos alunos, que os mesmos se envolveram nas tarefas propostas, cooperaram entre si, partilharam ideias, escutaram e ajudaram os outros, distribuíram tarefas entre si e tomaram decisões em conjunto - "tiveram que aprender a lidar com o colega do lado", "a saber perder", "a saber respeitar" (entrevista final à professora). A este propósito, na mesma entrevista, a docente salientou a experiência como muito positiva para todos os alunos, com mais e menos dificuldades, e o facto de terem percebido "que não podem ser tão egocêntricos e que também têm que partilhar" e que "ganharam alguma consciência das suas dificuldades em grupo". Outro aspeto salientado pela docente foi a forma como reagiram os melhores alunos da turma, que, na sua opinião, demonstraram mais dificuldades em trabalhar em grupo, embora apenas uma (AM) tenha demonstrado uma evolução mais lenta e menos significativa do que os outros alunos igualmente bons.

Pelos dados sociométricos da segunda aplicação do questionário, e comparando com os dados obtidos na primeira aplicação, verificou-se que existiam alguns atritos dentro de alguns grupos. Isto poderá ser explicado pelo facto de os alunos não estarem habituados a partilhar os seus saberes e a confrontarem-se de uma forma mais intensa e direta com as suas diferenças cognitivas e comportamentais - o que nos pareceu igualmente enriquecedor pelo crescimento que neles provocou. Apesar disso, a qualidade dos relacionamentos/amizades não foi afetada, havendo apenas pequenas alterações nas escolhas dos colegas de carteira e de trabalho de grupo, pouco relevantes. Manteve-se o número bastante elevado de reciprocidades nas escolhas dos alunos. A nível das rejeições, as reciprocidades surgem em 
número bastante reduzido (4 no total); registaram-se 3 rejeições recíprocas a mais, comparativamente com a matriz das rejeições da primeira aplicação do questionário, duas delas em relação a alunos que pertenciam ao mesmo grupo (DS/MM e VF/MF), o que será um facto a ser analisado, na continuação do projeto, embora possamos adiantar que, no decorrer das sessões, os alunos se iam revelando cada vez mais críticos e conscientes do seu papel e do dos outros.

No que diz respeito ao desempenho académico, de acordo com o que refere a docente titular da turma na segunda entrevista, "os alunos aprenderam a construir textos", "aprenderam muita coisa assim em grupo, ao trabalhar desta forma"; a docente salientou ainda que "esta experiência os ajudou muito na Língua Portuguesa" e que, se fosse feita com mais frequência, "tinham feito mais progressos". Outro dado relevante, em relação a uma das situações-problema detetadas - separação dos alunos em termos de anos de escolaridade e acentuação da discrepância cognitiva entre $2^{\circ}$ e $3^{\circ}$ anos, pelo método utilizado inicialmente -, é o facto de, tal como refere a docente na segunda entrevista, os alunos de ambos os anos terem saído enriquecidos em termos cognitivos, pela partilha de saberes em grupos cooperativos: " sim, acho que deu para o $3^{\circ}$ ano se aproximar mais do grupo

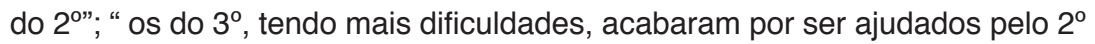
ano"; e " eles puderam partilhar e trabalhar competências de $3^{\circ}$ ano que o $2^{\circ}$ ainda não tinha aprendido e isso motivou-os bastante".

No que se refere aos casos particulares, salientam-se sobretudo os alunos MA, AM, VF, RR, DS, por diferentes motivos.

Em primeiro lugar, de referir a evolução da aluna MA, considerada com necessidades educativas especiais, evolução que se encontra referenciada em todo o discurso proferido pela professora titular de turma na segunda entrevista, nas avaliações dos seus desempenhos sessão a sessão, bem como também na segunda observação naturalista - dados que contrastam com os da recolha inicial. O Percurso da $M A$ foi registado com uma frequência de setenta e uma (71) unidades de registo na categoria. A docente referiu, assim, os resultados positivos do trabalho realizado com a aluna - "este projeto foi muito bom para ela"; "ela deu um salto, que a mim me deixa extremamente satisfeita"; "eu fiquei muito contente com os progressos da MA". Particularmente no que se refere aos aspetos sociais/relacionais, 
patentes na primeira subcategoria da segunda entrevista, as 25 unidades de registo apontam para o aumento da sua capacidade de reagir às situações mais adversas, em grupo. De uma criança insegura, apática, nervosa, que "tentava passar despercebida", a aluna foi gradualmente assumindo uma postura autoconfiante e uma maior capacidade em se relacionar com os seus colegas: "deixou de esfregar as mãos com aquele nervosismo", "passou a ser mais segura", "a marcar a posição dela", "passou a refilar", "a ter segurança nela própria". Este facto encontra-se igualmente bem visível na aula observada, onde se vê a aluna interagir com os seus dois colegas de grupo: "A MA repete: 'Olha este está mal"'; "A MA diz, batendo no braço do DL para o chamar: 'Olha, és tu!'” e "apronta-se logo para escrever". O facto de a aluna ter alargado o seu leque de amizades é visível nas três técnicas de recolha dinâmica de dados pós-intervenção, verificando-se na relação empática que estabeleceu com o seu colega DL (reciprocidade na escolha), pautada pela cooperação havida ao longo das sessões, no trabalho entre os dois, e pela compreensão e respeito do DL em relação ao ritmo da colega. Este facto é confirmado pela docente, ao referir que "ela até conseguiu descobrir, com este método, amizades que ela não sabia sequer que tinha" e que "conseguiu construir ali amigos".

Relativamente aos desempenhos académicos da MA, destacam-se os resultados obtidos quer nas tarefas desenvolvidas no âmbito do projeto, quer na sua avaliação final do ano, em Língua Portuguesa, ao nível do Bom. A docente opinou que "a aluna evoluiu" e que esta forma de trabalho a ajudou a apreender melhor os conteúdos de Língua Portuguesa, opinião que se torna consistente pela quantidade de unidades de registo (14) que se integram na subcategoria Progressos ao nível académico, onde é salientado, a título de exemplo, que "se tivesse sido sempre de uma forma tradicional, estou a falar dos verbos concretamente, por exemplo, que é um conteúdo difícil para ela, ela se calhar não tinha conseguido adquirir como adquiriu assim".

No que se refere à sua Inclusão educativa, as 32 unidades de registo da subcategoria referida remetem para melhorias significativas no que se refere à forma como os seus pares passaram a 'olhá-la', na sequência da sua participação mais interventiva nas atividades. Novamente comparando com os dados obtidos inicialmente, os aspetos que mais relevam dos dados apurados remetem para o facto de a intervenção realizada ter contribuído 
para que a aluna se sentisse uma igual entre os seus pares, referindo a docente, na segunda entrevista, que "nesses dias, então, do projeto, ela sentia-se meeeeeesmo igual aos outros", passando de uma situação inicial em que "ela no início era vista como a coitadinha" para uma situação em que "os outros também aprenderam mais a respeitá-la" e "viram que ela também conseguia dar ideias", em que ela própria se mostrava automotivada, participando, colocando o dedo no ar, 'puxando' os colegas para o trabalho, querendo ser porta-voz em frente a toda a turma e desempenhar outros papéis no grupo, como por exemplo o de "escriba".

No que diz respeito a outros casos com perfis mais diferenciados, salienta-se o aluno VF com uma evolução positiva. Os dados obtidos na entrevista e na observação iniciais, concretamente 8 unidades de registo da subcategoria relativa à sua ausência de envolvimento na atividade observada, contrapõe-se com um maior envolvimento e participação nas tarefas: "Contribuiu com ideias para a construção de histórias, em grupo"; "em grupo, essa característica do VF foi realçada, funcionou muito bem" (opinião da docente). As 9 unidades de registo relativas ao VF, identificadas na subcategoria Casos particulares/categoria Envolvimento dos alunos na atividade, corroboram a sua evolução.

A AM apresentou-se, ao longo da intervenção, também como um caso particular, na medida em se verificaram dificuldades ao nível das competências sociais, na aceitação e respeito pelas opiniões/ideias dos outros, sobretudo dos que percecionava como sendo menos fortes do que ela cognitivamente. Conforme as avaliações que dela foram feitas ao longo das sessões, ao nível das competências sociais e de acordo com a docente titular da turma, "a trabalhar em grupo foi uma diferença e aí ela mostrou toda a faceta que ela tem em casa", "na relação com os colegas, muito conflituosa", "não deixava que as outras pudessem também dizer o que sabiam" e "não aceitava a opinião de determinados colegas, principalmente dos que tinham mais dificuldades". Fez uma pequena evolução, mostrando-se um pouco mais diplomática e solidária e admitindo as qualidades de alguns com quem não empatizava inicialmente: "a mim surpreendeu-me ela ter funcionado assim tão bem com ele [VF]" (registo da docente titular de turma). Não se verificaram todos os resultados esperados relativamente a esta aluna, tendo ainda, como refere a docente na entrevista e como se pode ver na observação e nas suas 
avaliações das sessões, um percurso pessoal a fazer neste domínio: "ela percebeu qualquer coisa... mas precisa de mais".

Quanto aos alunos RR e DS, ambos com comportamentos instáveis e algo excluídos pelos colegas ao longo das sessões de intervenção (embora apenas rejeitados por três colegas numa única opção, no caso do DS, e por dois colegas no caso do RR, na primeira matriz sociométrica de rejeições), verificou-se alguma evolução, mais significativa no aluno $R R$ do que no aluno DS. Verificou-se uma maior aceitação do RR por parte dos colegas do grupo onde permaneceu mais tempo. Este aspeto é visível na observação final realizada, onde o $\mathrm{RR}$ participou na realização da atividade no seio do seu grupo: "O RR colabora na tarefa"; "o RR conversa com o colega sobre o trabalho". Verificam-se 9 unidades de comportamento deste tipo de dados, na subsubcategoria RR, integrada na categoria Envolvimento dos alunos na atividade da grelha de análise da segunda observação. No caso do DS, a situação não teve uma evolução tão favorável, embora o grau de exclusão não tivesse nunca atingido proporções muito negativas no seio dos grupos que integrou. Pudemos, contudo, constatar, pelos dados da segunda observação (9 unidades na subsubcategoria DS/categoria Envolvimento dos alunos na atividade), a sua maior entrega, 'presença' na atividade e esforço em contribuir com a sua parte para a realização da tarefa em causa: "O DS regista as opções, questiona os colegas".

De salientar que o facto de os alunos terem tido objetivos diferenciados - o RR em ambas as áreas (social e académica) e o DS na área social poderá ter contribuído para a ligeira melhoria, sobretudo nas sessões finais da intervenção, visto que, tal como refere a docente, estes alunos "não se conseguiam concentrar e alheavam-se um bocado", aspeto que foi bem notório nos primeiros dois terços da intervenção. No quadro abaixo encontrase exposto, de forma esquemática, o percurso de mudança evidenciado pelos dados recolhidos nas duas fases distintas. 


\section{Quadro VI - Síntese da intervenção focalizada nos alunos - Dados comparativos}

\begin{tabular}{|c|c|c|c|}
\hline Âmbito & \multicolumn{2}{|c|}{ Situação inicial } & Resultados obtidos \\
\hline 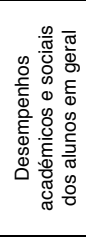 & \multicolumn{2}{|c|}{$\begin{array}{l}\text { - Ausência de interações horizontais; } \\
\text { - Subaproveitamento, nos contextos de } \\
\text { aprendizagem, dos bons relacionamentos } \\
\text { interpessoais entre os alunos; } \\
\text { - Discrepâncias acentuadas ao nível do rendimento } \\
\text { escolar entre os dois anos de escolaridade ao nível } \\
\text { da Língua Portuguesa e da Matemática. }\end{array}$} & $\begin{array}{l}\text { - Aumento das interações horizontais; } \\
\text { - Crescimento social dos alunos, talvez pela } \\
\text { mediação de conflitos em situação de } \\
\text { aprendizagem; } \\
\text { - Regulação do espírito competitivo dos } \\
\text { melhores alunos, com exceção de uma aluna; } \\
\text { - Evolução de } 4 \text { dos } 5 \text { grupos (competências de } \\
\text { cooperação e académicas); } \\
\text { - Melhoria das competências em Língua } \\
\text { Portuguesa em alguns alunos do } 3^{\circ} \text { ano. }\end{array}$ \\
\hline \multirow{2}{*}{ 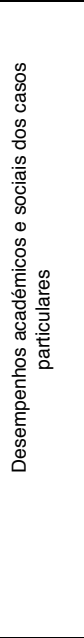 } & MA & $\begin{array}{l}\text { - Participação oral nula na sala de aula; } \\
\text { - "Excessiva" dependência do professor; } \\
\text { - Nervosismo e insegurança/falta de } \\
\text { crença em si própria; } \\
\text { - Algum isolamento/amizades restritas; } \\
\text { - Dificuldades em Língua Portuguesa } \\
\text { (ex.: bloqueio perante tarefas de } \\
\text { produção de textos). }\end{array}$ & $\begin{array}{l}\text { - Participação nas tarefas propostas; } \\
\text { - Tomada de decisões face às atividades e às } \\
\text { atitudes dos colegas; } \\
\text { - Atitudes mais assertivas com os colegas; } \\
\text { - Sentimento de igualdade em relação aos seus } \\
\text { pares (pela sua postura na sala); } \\
\text { - Alargamento do círculo de amizades; } \\
\text { - Melhoria dos resultados na área de Língua } \\
\text { Portuguesa. }\end{array}$ \\
\hline & $\begin{array}{l}\text { Outros } \\
\text { casos } \\
\text { parti- } \\
\text { culares }\end{array}$ & $\begin{array}{l}\text { - AM: dificuldades ao nível das } \\
\text { competências sociais em contexto de } \\
\text { trabalho cooperativo (dificuldade em } \\
\text { aceitar as diferenças e respeitar as ideias } \\
\text { e as dificuldades dos colegas); } \\
\text { - VF: aluno desconcentrado/"alheado", } \\
\text { pouco participativo nas aulas; algo } \\
\text { excluído pelos colegas em contexto de } \\
\text { trabalho; } \\
\text { - RR: dificuldades de ordem socioafetiva } \\
\text { que interferiam nos seus desempenhos; } \\
\text { excluído pelos colegas; rejeitado pelos } \\
\text { colegas no trabalho; dificuldades de } \\
\text { aprendizagem de conteúdos académicos; } \\
\text { - DS: dificuldades no relacionamento } \\
\text { interpessoal em contexto e no } \\
\text { envolvimento nas tarefas. }\end{array}$ & $\begin{array}{l}\text { - AM: esforço por ser mais diplomática e } \\
\text { solidária; melhoria do espírito de cooperação; } \\
\text { continuação das dificuldades de aceitação de } \\
\text { ritmos de aprendizagem mais lentos dos colegas } \\
\text { com mais dificuldades; } \\
\text { - VF: valorizado pela sua criatividade; maior } \\
\text { aceitação pela turma em geral; elogiado pela } \\
\text { AM; } \\
\text { - RR: maior envolvimento nas tarefas; menor } \\
\text { discriminação por parte dos colegas, de uma } \\
\text { forma global, mantendo-se casos pontuais de } \\
\text { não-aceitação; melhoria dos resultados em } \\
\text { Língua Portuguesa com alguma diferenciação } \\
\text { dos objetivos académicos; } \\
\text { - DS: ligeira melhoria da sua participação, mais } \\
\text { nas últimas sessões; inclusão não totalmente } \\
\text { conseguida, embora sem dados relevantes de } \\
\text { rejeição na matriz sociométrica. }\end{array}$ \\
\hline
\end{tabular}

\section{Intervenção focalizada na parceria pedagógica e na dinâmica de} sala de aula

Tendo em conta os objetivos traçados para este domínio, e no que diz respeito concretamente à parceria pedagógica, verificou-se a construção gradual de uma efetiva parceria pedagógica entre nós e a docente titular de turma, visível pelas reflexões feitas sobre as sessões, pela forma como foi articulada a preparação das atividades e a reflexão conjunta sobre os desempenhos dos alunos, o decorrer das sessões e os aspetos a melhorar. Progressivamente, a docente assumiu o projeto como uma mais-valia para a sua prática profissional, apropriando-se dele como algo que a envolvia diretamente, e foi-se verificando uma tomada de decisões cada vez mais 
partilhada, relativamente a alterações a efetuar, na sala de aula ou na programação, atividades a realizar ou estratégias a implementar.

Apresentamos, de seguida, nos quadros VII e VIII, os dados mais relevantes dos enfoques em questão, recolhidos a partir da segunda aplicação das técnicas da entrevista e da observação naturalista.

\section{Quadro VII - Parceria pedagógica e metodologia implementada - Síntese dos dados obtidos na $2^{\mathrm{a}}$ entrevista à professora titular de turma}

\begin{tabular}{|c|c|l|}
\hline $\begin{array}{c}\text { Categorias / } \\
\begin{array}{c}\text { Total de } \\
\text { unidades de } \\
\text { registo }\end{array}\end{array}$ & $\begin{array}{c}\text { Subcategorias / } \\
\text { Total de unidades } \\
\text { de registo }\end{array}$ & \multicolumn{1}{c|}{ Sub-subcategorias / Total de unidades de registo } \\
\hline \multirow{2}{*}{$\begin{array}{c}\text { Avaliação do } \\
\text { projeto } \\
\text { desenvolvido } \\
(56)\end{array}$} & $\begin{array}{c}\text { Parceria } \\
\text { pedagógica (27) }\end{array}$ & $\begin{array}{l}\text { - Processo gradual de planificação e reflexão - cada vez mais partilhado e } \\
\text { frequente; } \\
\text { - Desejo de dar continuidade à parceria no ano letivo seguinte; } \\
\text { - Partilha e ajuda com orientações sobre todos os alunos e não só com a MA. }\end{array}$ \\
\cline { 2 - 4 } & $\begin{array}{c}\text { Metodologias } \\
\text { implementadas } \\
(29)\end{array}$ & $\begin{array}{l}\text { - Experiência muito enriquecedora; } \\
\text { - Meio eficaz para trabalhar competências; } \\
\text { - Necessidade de continuidade para se obterem mais resultados; } \\
\text { - Metodologias benéficas para todos os alunos e para a inclusão de alunos } \\
\text { com necessidades educativas especiais. }\end{array}$ \\
\hline
\end{tabular}

\section{Quadro VIII - Dinâmica de sala de aula - Síntese dos dados obtidos na $2^{\mathrm{a}}$ observação naturalista}

\begin{tabular}{|c|c|c|}
\hline $\begin{array}{l}\text { Categorias / } \\
\text { Total de } \\
\text { unidades de } \\
\text { registo }\end{array}$ & $\begin{array}{l}\text { Subcategorias / } \\
\text { Total de unidades } \\
\text { de registo }\end{array}$ & Sub-subcategorias / Total de unidades de registo \\
\hline \multirow{3}{*}{$\begin{array}{l}\text { Dinâmica da } \\
\text { sala de aula } \\
\qquad(57)\end{array}$} & $\begin{array}{l}\text { Gestão do } \\
\text { trabalho com dois } \\
\text { anos de } \\
\text { escolaridade } \\
\text { (17) }\end{array}$ & $\begin{array}{l}\text { - Alunos organizados em grupos heterogéneos; } \\
\text { - Professora como mediadora das aprendizagens (orienta, supervisiona, } \\
\text { sugere, ajuda a melhorar as produções escritas); } \\
\text { - Promoção da autonomia e da responsabilidade partilhada nos alunos, } \\
\text { durante a realização das tarefas. }\end{array}$ \\
\hline & $\begin{array}{l}\text { Natureza das } \\
\text { interações } \\
\text { verticais } \\
(15)\end{array}$ & $\begin{array}{l}\text { - Promoção de um clima positivo e cooperativo; } \\
\text { - Promoção da inclusão/aceitação das diferenças; } \\
\text { - Estimulação das potencialidades dos alunos. }\end{array}$ \\
\hline & $\begin{array}{l}\text { Estratégias } \\
\text { pedagógicas } \\
\qquad(20)\end{array}$ & $\begin{array}{l}\text { - Utilização de questões abertas aos elementos de cada grupo sobre as suas } \\
\text { histórias - estimulação da criatividade dos alunos; } \\
\text { - Colocação de questões que fomentaram a reflexão/avaliação por parte dos } \\
\text { alunos relativamente ao trabalho que iam realizando; } \\
\text { - Apelo à partilha de ideias entre os elementos de cada grupo }\end{array}$ \\
\hline
\end{tabular}

Das 56 unidades de registo da primeira categoria da entrevista em causa, 27 apontam para um bom trabalho de cooperação entre as duas docentes e uma articulação, quer na tomada de decisões, quer na concretização das atividades em sala de aula. A docente salienta que "foi 
muito positivo", dizendo "aliás, eu queria desde já dizer que acho que funcionámos muito bem as duas", e manifesta, por diversas vezes, o desejo de continuar a mesma parceria no ano letivo seguinte: "o que era bom era que pudéssemos continuar a trabalhar juntas com a turma que vou ter no próximo ano". Refere ainda que, inicialmente, as ideias não partiam tanto das duas, mas que "depois as ideias já iam fluindo de parte a parte" e que "já iam sendo de uma forma mais antecipada e em conjunto". Um dos aspetos valorizados pela docente nesta parceria foi a experiência da docente de educação especial ser professora de todos os alunos e não apenas da aluna com necessidades especiais: "também depois houve partilha de dicas tuas em relação a outros alunos que não eram propriamente, à partida, teus alunos"; "tu vias que era preciso fazer alguma coisa e essas dicas foram sempre todas dadas e foram também muito boas para mim"; "fomos falando sempre também acerca deles, daqueles casos mais particulares" e "não foi só centrado na MA". Estas unidades de registo mostram que, de facto, existiu um par pedagógico a trabalhar em conjunto com toda a turma e que se verificou um crescimento profissional de ambas as docentes, no sentido da autorreflexão e autoquestionamento sobre as suas práticas pedagógicas e as atuações em relação a cada aluno em particular.

Quanto à introdução de uma dinâmica de trabalho diferente em contexto de sala de aula, como se apresenta no quadro VII, também é possível concluir que a docente percecionou a aprendizagem cooperativa como uma metodologia vantajosa para todos os alunos e como uma experiência enriquecedora para si própria, considerando-a uma "experiência bastante positiva". Referiu que se sentiu bastante motivada e que se trata de uma metodologia que promove a inclusão não só de alunos com necessidades educativas especiais mas de outros alunos também: "Favorável, não! Eu acho que é excelente para a inclusão!"; "Aliás, eu acho que esse método é benéfico para qualquer aluno". Acrescentou que as metodologias utilizadas permitiram trabalhar competências de uma forma diferente e obter um conhecimento dos alunos também de um modo diferente, o que muitas vezes não é possível com métodos mais tradicionais: "Sim, acho que é um meio mais eficaz para trabalhar essas competências".

Os dados da observação são concordantes com os obtidos na entrevista no que se refere à dinâmica de sala de aula: 1) pelo papel assumido 
pela docente enquanto mediadora das aprendizagens: "Eu vou andar a circular pelos grupos"; 2) pela natureza das interações, promovendo um clima cooperativo e inclusivo: "Há grupos que demoram mais tempo, está bem?"; "Aproveitem as ideias dele que ele é muito criativo!" - referindo-se ao DS, um dos casos mais particulares; 3) e ainda pelo tipo de estratégias pedagógicas que desenvolve, promovendo a criatividade, a autonomia e a reflexão dos alunos sobre as suas atitudes e o trabalho desenvolvido: "A $P$ ajuda o grupo 2 na construção da história, colocando questões para eles desenvolverem as suas próprias ideias".

Comparando estes dados com os inicialmente recolhidos, foi possível verificar alterações significativas na gestão dos dois anos de escolaridade: na categoria Dinâmica da sala de aula de ambas as observações, subcategoria Gestão do trabalho com dois anos de escolaridade, as 25 unidades da primeira observação apontam para o trabalho em separado com os dois anos de escolaridade, contrastando com as 17 unidades da mesma subcategoria na segunda observação, que evidenciam o grupo-turma como um todo, em trabalho cooperativo independentemente do ano de escolaridade em que se encontrava cada um dos alunos. Também na subcategoria Natureza das interações verticais, na primeira observação as 25 unidades de comportamento que apontam para questões fechadas e instruções demasiado dirigidas contrastam com as 15 unidades da mesma categoria da segunda observação, evidenciando uma abordagem mais centrada nos alunos e nas suas potencialidades. Por último, os dados comparativos entre as duas observações na subcategoria Estratégias pedagógicas são reveladores de mudanças: 30 unidades de comportamento na primeira observação revelam uma tendência para responder às próprias perguntas e para colocar questões de exploração do texto conjugadas com as experiências pessoais dos alunos; na segunda observação, apurámos 21 unidades, registando estratégias mais estimuladoras do pensamento criativo e reflexivo nos alunos, fazendo-os questionar-se sobre o porquê, o como e o para quê das situações em análise.

Por último, salientamos um dado que nos parece relevante e revelador de algumas das mudanças conseguidas e que se prende com o impacto que teve, na docente, a metodologia implementada. A docente titular da turma expressou, por mais do que uma vez, na entrevista final, a intenção de 
implementar esta metodologia com a sua turma do ano letivo seguinte, ainda que considerando muito mais gratificante se pudesse fazê-lo em par pedagógico connosco, docente de educação especial: "Vou ver se... se não estiveres na minha sala para o ano, vou ver se faço isso com a minha turma".

O quadro abaixo apresenta um confronto entre os dados inicialmente recolhidos e os resultados obtidos no final do ano letivo relativamente ao percurso feito ao nível do trabalho de parceria pedagógica conseguido e da dinâmica de trabalho em sala de aula antes e após a intervenção.

\section{Quadro IX - Síntese da intervenção focalizada na Parceria pedagógica e na Dinâmica de sala de aula - Dados comparativos}

\begin{tabular}{|c|c|c|}
\hline Âmbito & Situação inicial & Resultados obtidos \\
\hline $\begin{array}{c}\text { Parceria } \\
\text { pedagógica }\end{array}$ & $\begin{array}{l}\text { - Inexistência de planificação de atividades em } \\
\text { conjunto; } \\
\text { - Estatuto da docente de educação especial } \\
\text { confinado ao trabalho com MA; } \\
\text { - Sobrevalorização da ideia da necessidade de } \\
\text { mais horas de apoio à aluna considerada com } \\
\text { necessidades educativas especiais, como } \\
\text { estratégia para ajudar a superar melhor as suas } \\
\text { dificuldades. }\end{array}$ & $\begin{array}{l}\text { - Planificação de atividades em conjunto; } \\
\text { - Mediação das aprendizagens por parte de ambas as } \\
\text { docentes, em parceria pedagógica na sala de aula; } \\
\text { - Reflexões conjuntas sobre os aspetos positivos/menos } \\
\text { positivos das sessões, os desempenhos dos alunos em } \\
\text { geral e dos casos particulares e a preparação das } \\
\text { atividades; } \\
\text { - Atitude compartilhada numa perspetiva de resolução de } \\
\text { problemas - observação, reflexão crítica sobre os aspetos } \\
\text { a melhorar e reformulações pedagógicas a realizar nas } \\
\text { sessões seguintes; daça da docente titular da turma para a } \\
\text { - Motivação da da aprendizagem } \\
\text { implementação da metodologia da } \\
\text { cooperativa com turmas futuras. }\end{array}$ \\
\hline $\begin{array}{l}\text { Dinâmica } \\
\text { da sala de } \\
\text { aula }\end{array}$ & $\begin{array}{l}\text { - Separação entre os alunos do } 2^{\circ} \text { e do } 3^{\circ} \text { anos; } \\
\text { - Ausência de promoção de interações entre os } \\
\text { alunos em tarefa (aluno-aluno e } 2^{\circ}-3^{\circ} \text { anos); } \\
\text { - Alternância entre } 2 \text { momentos: interação } \\
\text { alunos-professor / trabalho individual; } \\
\text { - Utilização de estratégias pedagógicas } \\
\text { centradas no professor e no diálogo } \\
\text { exclusivamente vertical: grande frequência de } \\
\text { questões fechadas, de fraco apelo à } \\
\text { reflexividade e criatividade; no contexto de } \\
\text { - Subaproveitamento, no das boas relações interpessoais } \\
\text { aprendizagem, das boutos mais } \\
\text { existentes entre os alunos em contextos } \\
\text { informais. }\end{array}$ & $\begin{array}{l}\text { - Um grupo-turma em vez de dois; } \\
\text { - Organização do trabalho em pequenos grupos } \\
\text { heterogéneos, em termos cognitivos e em termos de ano } \\
\text { de escolaridade; } \\
\text { - Diversificação do tipo de interações e dos momentos de } \\
\text { trabalho; } \\
\text { - Utilização de estratégias pedagógicas centradas no } \\
\text { aluno e na socialização dos saberes entre si: questões } \\
\text { abertas, apelando à criatividade e exigindo a construção } \\
\text { de um trabalho partilhado e a reflexão conjunta sobre os } \\
\text { aspetos a melhorar; } \\
\text { - Conflitos em situação de aprendizagem geradores de } \\
\text { crescimento pessoal/social nos alunos; } \\
\text { - Regulação do espírito competitivo dos melhores alunos; } \\
\text { - Promoção de um clima cooperativo e inclusivo. }\end{array}$ \\
\hline
\end{tabular}

\section{Intervenção focalizada na mãe da $M A$}

A intervenção a este nível teve como principal objetivo conduzir a mãe da MA a uma maior aceitação do perfil cognitivo da sua educanda e a uma maior confiança no trabalho dos agentes educativos responsáveis pela aprendizagem escolar. Os dados relativos a este enfoque da nossa intervenção foram obtidos através de duas técnicas: entrevistas à docente titular da turma e reuniões realizadas com a encarregada de educação. $O$ 
quadro abaixo apresenta uma síntese comparativa entre os dados da primeira entrevista e os dados da segunda entrevista, mostrando a evolução ocorrida entre as duas fases de recolha dinâmica dos dados.

\section{Quadro X - Intervenção focalizada na mãe da MA - Dados comparativos}

\begin{tabular}{|c|c|c|c|c|c|}
\hline \multicolumn{2}{|c|}{$\begin{array}{l}\text { Situação inicial } \\
\left(1^{\mathrm{a}} \text { entrevista) }\right.\end{array}$} & \multicolumn{4}{|c|}{ Resultados obtidos ( $2^{\mathrm{a}}$ entrevista) } \\
\hline $\begin{array}{l}\text { Categorias } \\
\text { / Total de } \\
\text { unidades } \\
\text { de registo }\end{array}$ & $\begin{array}{l}\text { Dados } \\
\text { relevantes }\end{array}$ & $\begin{array}{l}\text { Categorias } \\
\text { / Total de } \\
\text { unidades } \\
\text { de registo }\end{array}$ & $\begin{array}{l}\text { Subcategorias } \\
/ \text { Total de } \\
\text { unidades de } \\
\text { registo }\end{array}$ & $\begin{array}{c}\text { Sub- } \\
\text { subcategorias } \\
/ \text { Total de } \\
\text { unidades de } \\
\text { registo }\end{array}$ & Dados relevantes \\
\hline \multirow[b]{3}{*}{$\begin{array}{l}\text { A mãe da } \\
\text { MA } \\
(33)\end{array}$} & \multirow{3}{*}{$\begin{array}{l}\text { - Não aceitação } \\
\text { das dificuldades } \\
\text { da sua } \\
\text { educanda; } \\
\text { - Atitude de } \\
\text { "desconfiança" } \\
\text { face à escola: } \\
\text { pouca } \\
\text { informação } \\
\text { facultada, } \\
\text { evitamento de } \\
\text { contactos com a } \\
\text { docente titular } \\
\text { da turma; } \\
\text { - Sobrevaloriza- } \\
\text { ção das } \\
\text { terapias; } \\
\text { - Pressão e } \\
\text { trabalho } \\
\text { excessivo em } \\
\text { casa sobre os } \\
\text { conteúdos } \\
\text { curriculares. }\end{array}$} & \multirow[b]{3}{*}{$\begin{array}{l}\text { A mãe da } \\
\text { MA } \\
(39)\end{array}$} & \multirow{2}{*}{$\begin{array}{l}\text { Efeitos da } \\
\text { intervenção } \\
\text { realizada com } \\
\text { a mãe } \\
\text { (reuniões) } \\
\text { (27) }\end{array}$} & $\begin{array}{l}\text { Progressos } \\
\text { verificados } \\
\quad(18)\end{array}$ & $\begin{array}{l}\text { - Maior aceitação do perfil de } \\
\text { aprendizagem da sua educanda; } \\
\text { - Evolução na confiança nos } \\
\text { agentes educativos: maior } \\
\text { colaboração, partilha de } \\
\text { sentimentos, mais diálogo; }\end{array}$ \\
\hline & & & & $\begin{array}{l}\text { Ausência de } \\
\text { progressos } \\
\text { (9) }\end{array}$ & $\begin{array}{l}\text { - Dificuldades em lidar com o 'olhar' } \\
\text { da sociedade relativamente à } \\
\text { diferença. }\end{array}$ \\
\hline & & & $\begin{array}{l}\text { Efeitos da } \\
\text { intervenção } \\
\text { com a MA } \\
\text { (sala de aula) } \\
\text { na postura } \\
\text { da mãe } \\
\text { (12) }\end{array}$ & & $\begin{array}{l}\text { - Repercussões positivas do bem- } \\
\text { estar/autoconfiança da sua } \\
\text { educanda no seu próprio bem-estar } \\
\text { e tranquilidade relativamente aos } \\
\text { trabalhos escolares e aos } \\
\text { conteúdos curriculares; } \\
\text { - Compreensão da importância da } \\
\text { metodologia utilizada para o } \\
\text { desenvolvimento pessoal e social } \\
\text { da sua educanda e seus efeitos } \\
\text { nas aprendizagens académicas; } \\
\text { - Solicitação às docentes, no final } \\
\text { do ano letivo, de continuidade do } \\
\text { projeto no ano letivo seguinte, na } \\
\text { área da Matemática. }\end{array}$ \\
\hline
\end{tabular}

Da recolha inicialmente realizada, quer pela primeira reunião, quer pela primeira entrevista à docente titular da turma, verificava-se que a encarregada de educação apresentava dificuldade em aceitar as dificuldades da MA. Sobrevalorizava as terapias de que a mesma usufruía, desvalorizando um pouco o trabalho feito pela escola, mostrando uma atitude de pouca confiança no trabalho realizado na sala de aula. Mantinha algum evitamento do diálogo com a docente titular da turma, tendo esta salientado, na entrevista, que a mãe "não encara a professora titular", escondendo alguns factos do percurso da sua educanda, nomeadamente, segundo a docente, alguns relatórios importantes: "Eu acho que, no fundo, ela tenta camuflar o problema da filha e não a ajuda". Verificou-se ainda que a encarregada de educação tentava colmatar as limitações da MA em casa, ajudando-a e trabalhando arduamente com ela, durante várias horas por dia. A elevada 
frequência de unidades de registo elencados (33) levou-nos à consciencialização da situação-problema a este nível e a direcionar uma parte da intervenção para este âmbito.

Assim, através das reuniões e conversas informais realizadas com a encarregada de educação, onde foi sendo explicada a forma como as docentes atuavam com a MA, foi possível percecionar o modo como a mesma ia recebendo o feedback da sua educanda em casa, sobre as sessões de intervenção, e como ia reagindo ao trabalho com ela realizado pelas docentes. A este nível, conforme pudemos comprovar, na segunda entrevista, pelas 18 unidades de registo da primeira subsubcategoria integrada na categoria Efeitos da intervenção realizada com a mãe (reuniões), verificou-se um percurso de aceitação das limitações cognitivas da sua educanda: "fazer o luto e aceitar a filha da maneira que ela é, que em parte já fez este ano"; "pelo menos agora, acho que isso ela já aceitou mais"; a própria mãe "concordou que de facto se tratava de uma grande dificuldade da aluna e que, por vezes, mesmo em casa, parecia que já sabia e no dia seguinte esquecia tudo".

Verificou-se, igualmente, por parte da mãe da MA, uma progressiva abertura face às propostas de trabalho que foram sendo apresentadas pelas docentes, não só em relação ao trabalho em grupos cooperativos sobre os conteúdos de Língua Portuguesa, como também à forma como iam sendo realizadas as adequações curriculares, ajustamentos nas suas fichas de avaliação, estratégias curriculares e didáticas implementadas no dia-a-dia da sala de aula: "a mãe respondeu que entendia que, para já, as coisas estavam a correr bem e que se iria vendo ao longo do tempo se haveria algo mais a fazer". A docente titular de turma salientou que "perante nós, eu acho que ela evoluiu da noite para o dia", que "ela percebeu que tinha uma equipa a trabalhar com a filha", "que a equipa estava a funcionar" e "que havia um elo de ligação, tanto na psicóloga, como na professora titular, como na professora de educação especial". A docente referiu ainda que a mãe acabou por confiar no trabalho realizado pelas docentes - "acho que ela se sentiu apoiada e compreendida por nós" - e que, face a essa mudança, a mãe "já fala mais". Este processo de confiança na escola acabou por ter repercussões na maior valorização do trabalho nesse contexto em detrimento de uma das terapias de que a aluna iria voltar a beneficiar no $3^{\circ}$ período e, por coincidência de horário, 
a mãe decidiu deixar a MA na escola à quinta-feira, desejo expresso numa das reuniões realizadas, em que referiu que "talvez fosse melhor para a MA ficar na escola já que também acabavam por trabalhar aquelas competências de grupo e pelo menos estava a trabalhar ao mesmo tempo os conteúdos de Língua Portuguesa".

Relativamente ao impacto, na encarregada de educação, da intervenção com a MA na sala de aula, nas sessões desenvolvidas no âmbito do projeto, também se fez sentir e é constatado pelos dados obtidos, quer pela entrevista à docente - 12 unidades de registo são reveladoras da satisfação da mãe perante a forma como a MA se sentia -, quer pelas reuniões e conversas realizadas, referindo a própria mãe que a sua educanda estava mais solta, que "nesses dias, ia muito satisfeita e que a notava mais entusiasmada com as tarefas que realizava, contando o que tinha estado a fazer". A docente referiu, na sua entrevista, que a mãe foi "no fundo, o espelho e o reflexo daquilo que a filha sentiu" e que "a mãe sentiu que a filha estava mais igual aos outros", salientando, como reflexo do bem-estar de ambas, o agradecimento da mãe no final do ano letivo: "aquele agradecimento no fim, ... eh... foi todo esse reflexo". Outro aspeto relevante prende-se com o facto de a mãe ter demonstrado interesse em que, no ano letivo seguinte, fosse dada continuidade ao projeto, na área da Matemática: "demonstrando interesse em que fossem trabalhados conteúdos de Matemática"; "a ideia agradou à encarregada de educação que referiu que é muito bom para eles este tipo de trabalho, pois eles sentem-se mais motivados. Mesmo o JM [irmão da MA], apesar de ser bom aluno, também se mostra interessado naquelas atividades".

Por último, de referir que, apesar de se terem verificado os resultados positivos no que se refere aos objetivos traçados, a mãe da MA - como sugerem as 9 unidades de registo da subsubcategoria Ausência de progressos, da segunda entrevista - ainda não conseguia assumir totalmente a sua filha perante a sociedade em geral, referindo a docente que a incomoda o olhar dos outros relativamente às limitações da sua educanda: "ainda não conseguiu dar esse salto", "não tem aquela estaleca para, se vir alguém a olhar para a filha, dizer... qual é o problema, é a minha filha", deixando perceber que, na sua opinião, se trata de uma mãe difícil e que "ainda tem muito para dizer". 


\section{Discutindo e concluindo}

Enveredar por um processo de mudança orientado por uma metodologia de investigação-ação é, inevitavelmente, chegar ao fim de um percurso com a ideia de que muito existe ainda para concretizar. É, também, uma contínua reflexão sobre a ação e ação para nova reflexão, num processo cíclico e em espiral, num "aprender fazendo", construtor de professores capazes de fazer/experimentar, para dar resposta ao "arco-íris" das suas salas de aula (Sanches, 2011a).

Consideramos que, apesar de maioritariamente alcançados os objetivos a que nos propusemos inicialmente, a mudança implementada, para além de ter tido algumas limitações, que explicitaremos ao longo desta reflexão, apela a novos desafios de mudança. Por um lado, melhorar o que foi feito, e, por outro, chegar mais longe, todos os dias, mudando mentalidades, cooperando com os colegas no sentido da inclusão educativa, melhorando a qualidade das aprendizagens de todos os alunos, em geral, e dos alunos com necessidades educativas especiais, em particular.

No que se refere ao processo de intervenção em sala de aula, conseguimos implementar uma pedagogia diferenciada, tentando atender ao máximo às necessidades de cada aluno, quer fossem académicas ou de carácter social, introduzindo, a partir da sessão número 5 , objetivos e avaliação diferenciados não só para a MA, como também para aqueles alunos que se nos foram afigurando como casos mais particulares. Através da observação, gestão das atividades e dos alunos e das reflexões que fomos realizando, verificámos a necessidade de proceder a ajustamentos, os quais foram sendo realizados sessão após sessão, nomeadamente: ajustamentos pontuais na constituição dos grupos, quando se verificou ser mais vantajoso para determinados alunos, por motivos diversos; alterações de estratégias como o passar a registar as regras de trabalho cooperativo no quadro e os objetivos da sessão, enquanto os mesmos não fossem interiorizados pelos alunos, em vez da sua verbalização inicial, apenas; solicitação, aos alunos, de relembrarem por si próprios os objetivos do trabalho cooperativo, numa fase já mais adiantada da intervenção; alteração dos procedimentos na auto e heteroavaliação dos alunos e dos grupos; entre outros. Contudo, parece-nos que, em intervenções futuras, será necessário pensar noutras estratégias 
mais objetivas e construir instrumentos mais eficazes para melhor promover a capacidade de reflexão crítica (auto e heteroavaliação) nos alunos, sobretudo quando se trata de crianças de faixas etárias mais baixas, como era o caso da nossa turma, item em que se verificou uma menor evolução dos alunos em geral. Por outro lado, e embora Lopes e Silva (2009) salientem que "qualquer tarefa, de qualquer matéria e de qualquer programa de estudos pode organizar-se de forma cooperativa" (p. 21), consideramos que há que ajustar o grau de complexidade das atividades em função, quer da experiência dos alunos neste tipo de metodologia, quer da sua maturidade/idade. Embora, pelo percurso realizado, tenhamos verificado que as atividades mais complexas tenham sido aquelas que mais estimularam os alunos, consideramos que, para um professor menos experiente neste tipo de metodologias, será mais cauteloso começar por atividades menos exigentes para si e para os alunos, tendo em conta que as variáveis a gerir no momento da concretização aumentam em número e em grau de dificuldade e podem comprometer o sucesso da atividade em causa, ainda que a mesma seja objeto de uma rigorosa planificação.

Quanto à articulação do trabalho com a docente titular de turma, tratouse de um processo de mudança gradual, em que a mesma passou de uma atitude passiva, diríamos mesmo alheia ao que se ia passando na sala de aula, nas primeiras sessões, para uma postura empenhada e totalmente envolvida no processo. Acabou, ela própria, por se deixar integrar como destinatária deste processo de mudança, alterando as suas práticas pedagógicas, tendo em conta que, algumas vezes, as atividades das sessões foram terminadas/realizadas exclusivamente pela docente titular da turma, tornando-se mais reflexiva sobre as dinâmicas que promove na sua sala de aula e desejando ir mais longe no seu percurso profissional, tal como preconizam Leitão (2007), Toledo e Vitaliano (2010) e Sanches (2011a), entre outros. Foram realizados, em conjunto com a docente titular de turma, os passos considerados essenciais a implementar pelo professor numa dinâmica cooperativa em sala de aula (Lopes \& Silva, 2009). Foram tomadas decisões antes da concretização da aula, em cada sessão foram explicitados os objetivos da atividade e do trabalho cooperativo, explicada a tarefa aos alunos, distribuídos entre si os papéis de cada um, supervisionada a aprendizagem dos mesmos, através de uma intervenção contínua junto dos 
grupos, apoiando na realização das tarefas, avaliados os desempenhos dos alunos e, por fim, promovida a reflexão sobre o grau de eficácia com que os grupos haviam funcionado.

Deste modo, muito embora nem tudo tenha sido conseguido como seria desejável, com o nosso projeto de investigação pudemos constatar que a diferenciação pedagógica e a inclusão educativa são, de facto, concretizáveis, desde que orientadas por estratégias e posturas não discriminatórias, isto é, envolvendo todos os alunos em metodologias onde a diferença cabe, não como uma discriminação negativa, mas como uma maisvalia de rendibilização da diversidade (Roldão, 2003). Verificámos que a aprendizagem cooperativa no seio de uma turma constitui um dos meios eficazes para colocar em prática essa diferenciação positiva, permitindo respeitar ritmos, estilos e capacidades de aprendizagem diversos e desenvolver diferentes tipos de competências nos alunos, enriquecendo-os como pessoas e preparando-os melhor para a vida, enquanto futuros cidadãos ativos, tal como afirmam Slavin (1991) e Bessa e Fontaine (2002a), entre outros.

As metodologias ativas, de que a aprendizagem cooperativa é um dos exemplos, favorecem um crescimento do ponto de vista pessoal e social, uma vez que, pela própria natureza das estratégias, é exigido aos alunos que trabalhem recursos internos, como o auto e heteroconhecimento. PermitemIhes, ainda, aprender a fazer cedências e a tornar-se mais flexíveis, a respeitar as diferenças e as ideias dos outros, tornando-se mais solidários e menos competitivos entre si, e a saber ser assertivos na negociação e tomada de decisões em conjunto, percebendo que o sucesso de cada um depende do sucesso do grupo (Bessa \& Fontaine, 2002b) e de uma boa gestão de todos estes aspetos conjugados. Daqui decorre toda a evolução positiva que os alunos poderão fazer em termos das suas aprendizagens académicas, já que tais dinâmicas de trabalho se constituem como uma via para trabalhar competências curriculares diversas, independentemente da área de conhecimento em questão ou da faixa etária/nível de escolaridade dos alunos. Como referiu a docente titular da turma, na intervenção realizada "trabalhámos na mesma as competências de Língua Portuguesa necessárias e adequámos às necessidades da turma".

Verificámos que as práticas cooperativas inclusivas têm um impacto 
positivo a diversos níveis, não se restringindo, pela sua natureza abrangente, à inclusão dos alunos com necessidades educativas especiais. A este nível, pensamos que se encontra bem fundamentado, pelos dados recolhidos, todo o percurso positivo efetuado pela aluna MA com a intervenção realizada, independentemente das dificuldades que persistem e constituem uma característica permanente do seu perfil cognitivo. Referindo-nos ao impacto nos alunos em geral, com ou sem dificuldades escolares, os ganhos que se obtêm refletem-se em todo o grupo e em cada aluno individualmente, como se verifica nas avaliações e reflexões das sessões semanais. Obrigam, como refere a docente titular de turma, a observar de forma mais eficaz e a recolher informação mais completa sobre os alunos. Assim, a intervenção é mais direcionada para as necessidades de cada um: "em grupo nós vemos neles o que não conseguimos ver se a aula for de uma forma mais individual"; "foi engraçadíssimo ver determinado tipo de coisas, que eu não consigo ver, lá está, se estiver a trabalhar individualmente".

Pela experimentação realizada, verificámos o contributo válido da aprendizagem cooperativa para o trabalho de aceitação das diferenças por parte das crianças, mostrando ser uma metodologia facilitadora da inclusão educativa. Somos levados a concordar com Lopes e Silva (2009, p. 10) no que se refere à eficácia dos múltiplos métodos que a compõem, "na aquisição, pelos alunos (...) de competências sociais a par da realização de aprendizagens cognitivas", aplicáveis a inúmeras situações educativas e conteúdos das diferentes áreas do saber, constituindo-se, na sua opinião, como uma boa alternativa para "ultrapassar as limitações da metodologia tradicional" muitas vezes estimuladora da exclusão e da competitividade entre pares no contexto escolar.

Burden (s/d, cit. por Lopes \& Silva, 2009), entende que "a cooperação é a convicção plena de que ninguém pode chegar à meta se não chegarem todos" (p. 3). Sabemos, pela experiência que desenvolvemos, que não só essa convicção deve estar bem presente na formação e atuação de professores, mas também os alunos devem ser contagiados com essa mesma convicção para que, de facto, a cooperação seja uma realidade na concretização de aprendizagens académicas; sabemos, também, que tal convicção apenas poderá emergir de uma experimentação efetiva e continuada, que vá muito para além de um projeto de intervenção limitado no 
tempo. Da frequência com que se implementam estas dinâmicas cooperativas/inclusivas numa turma depende o maior ou menor progresso dos alunos e o sucesso da metodologia, devendo salientar-se que, no âmbito do projeto realizado, uma das suas principais limitações apontará para o facto de apenas ter sido possível desenvolvê-lo uma vez por semana, em termos médios e durante um curto espaço de tempo (5 meses). A maior frequência/sistematicidade da implementação da metodologia, bem como a sua aplicação com outros conteúdos curriculares, poderia ter proporcionado a obtenção de melhores resultados sociais e académicos na turma.

Uma outra questão que nos parece relevante no que se refere ao impacto das metodologias utilizadas é o facto de as mesmas irradiarem aspetos positivos para além dos próprios alunos. Por exemplo, a sua implementação poderá provocar no professor, conforme verificámos na parceria pedagógica estabelecida, não só uma automotivação, pela implementação de estratégias mais estimulantes, das quais o docente poderá colher uma maior gratificação e satisfação profissionais, mas também o abandono da postura de transmissor de informação e a assunção de um papel ativo como mediador de aprendizagens. Por outro lado, é-Ihe exigida uma maior capacidade de reflexão sobre o seu próprio desempenho em sala de aula, o que o ajudará a progredir profissionalmente e a ter uma maior acuidade na observação das aprendizagens realizadas pelos alunos na aula, as quais, muitas vezes, apenas são apuradas através dos momentos de avaliação formal escrita, sujeitos aos condicionalismos da 'data marcada', para perceber o que o aluno compreendeu/não compreendeu, valorizando-se mais o produto e descurando-se todo o processo de construção de saberes, no quotidiano da sala de aula. Este projeto contribuiu para que, tanto nós como a docente titular de turma, assumíssemos mais o papel de mediadoras do que de transmissoras, para que tenhamos observado com maior qualidade as necessidades, posturas e desempenhos dos alunos, para obter uma maior capacidade autocrítica/reflexiva sobre as nossas próprias intervenções nas aulas e para fazer dos alunos os sujeitos ativos das suas aprendizagens.

Gostaríamos de salientar também que, pela intervenção que realizámos com a mãe da MA, pela observação dos factos iniciais, pelo seu progressivo acolhimento positivo das sugestões e estratégias implementadas, pela gradual diminuição da sua ansiedade perante o percurso escolar da sua 
educanda, retiramos uma reflexão que nos parece consistente e passível de ser testada em estudos posteriores: é nosso entendimento que a forma como os pais se relacionam com a escola, com os docentes e com o processo de aprendizagem dos seus educandos parece ser orientada e filtrada pela forma como os próprios filhos interagem com a escola, nos seus relacionamentos com colegas e professores e com os seus sucessos/insucessos escolares. As atitudes dos pais face à escola são muitas vezes o reflexo do bem-estar, ou da ausência dele, nos seus educandos, relativamente à sua vida escolar. Neste sentido, pensamos poder afirmar que o trabalho desenvolvido na sala de aula com o grupo, e em particular com a MA, facilitou uma certa inflexão no olhar desta encarregada de educação face à escola e ao suporte que nela pode encontrar para lidar com as dificuldades da sua educanda, mas também com as suas próprias dificuldades em relação às limitações da mesma. Esta experiência, que não pôde ser extensiva a todos os encarregados de educação, veio confirmar a necessidade, por nós sentida, de implicar ativamente os encarregados de educação no processo educativo dos seus educandos.

Cooperar e diferenciar para incluir, para tornar o ato educativo acessível a todos e com todos, é tão 'sonhável' quanto concretizável, ou não fosse o "sonho quem comanda a vida", como nos diz A. Gedeão (1956), ou Perrenoud (2001), quando afirma: "mesmo quando não levam a nada, mesmo quando a renúncia deixa o professor insatisfeito, os sonhos de diferenciação fazem avançar a sua reflexão" (p. 41).

\section{Notas}

1 Nome de código.

2 Dados recolhidos através de pesquisa documental.

\section{Referências}

Ainscow, M. (1999). Understanding the development of inclusive schools. London: Falmer Press.

Bessa, N., \& Fontaine, A. (2002a). A aprendizagem cooperativa numa pós-modernidade crítica. Educação, Sociedade \& Culturas, 18, 123-147. 
Bessa, N., \& Fontaine, A. (2002b). Cooperar para aprender - Uma introdução à aprendizagem cooperativa. Porto: Edições ASA.

Booth, T., Ainscow, M., Black-Hawkins, K., Vaughan, M., \& Shaw, L. (2000). Index for inclusion: Developing learning and participation in schools. Bristol: Center for Studies on Inclusive Education.

Correia, L. (2008). A escola contemporânea e a inclusão de alunos com NEE Considerações para uma educação com sucesso. Porto: Porto Editora.

Fontes, A., \& Freixo, O. (2004). Vygostky e a aprendizagem cooperativa. Lisboa: Livros Horizonte.

Freinet, C. (1975). As Técnicas Freinet da Escola Moderna. Lisboa: Editorial Estampa.

Freitas, M., \& Freitas, C. (2002). Aprendizagem cooperativa. Lisboa: Edições ASA.

Gardou, C. (2003). Inclusão escolar das crianças e adolescentes em situação de handicap: Uma revolução cultural necessária ou do homo sapiens ao homo socians. Revista Lusófona de Educação, 2, 53-66.

Gedeão, A. (1956). Movimento perpétuo. Coimbra: Atlântida.

Heacox, D. (2006). Diferenciação curricular na sala de aula. Como efectuar alterações curriculares para todos os alunos. Porto: Porto Editora.

Johnson, D., Johnson, R., Johnson, J., \& Anderson, D. (1976). Effects of cooperative versus individualized instruction on student prosocial behavior, attitudes toward learning and achievement. Journal of Educational Psychology, 68, 446-452.

Leitão, F. (2006). Aprendizagem cooperativa e inclusão. Cacém: Editor Ramos Leitão.

Leitão, F. (2007). Aprendizagem cooperativa e inclusão. Comunicação apresentada no Fórum de Estudos de Educação Inclusiva, Faculdade de Motricidade Humana da Universidade Técnica de Lisboa.

Lopes, J., \& Silva, H. (2009). A aprendizagem cooperativa na sala de aula. Um guia prático para o professor. Lisboa: Lidel.

Mittler, P. (2000). Working towards inclusive education. Londres: Fulton.

Morgado, J. (2005). Currículo e profissionalidade docente. Porto: Porto Editora.

Perrenoud, P. (2001). A pedagogia na escola das diferenças. Fragmentos de uma sociologia do fracasso ( $2^{\mathrm{a}}$ ed.). Porto Alegre: Artmed Editora.

Rodrigues, D. (2003). Perspetivas sobre a inclusão. Da educação à sociedade. Porto: Porto Editora.

Roldão, C. (2003). Diferenciação curricular e inclusão. In D. Rodrigues (Org.), Perspectivas sobre a inclusão. Da educação à sociedade. Porto: Porto Editora.

Sanches, I. (2001). Comportamentos e estratégias de actuação na sala de aula. Porto: Porto Editora.

Sanches, I. (2005). Compreender, agir, mudar, incluir. Da investigação-acção à educação inclusiva. Revista Lusófona de Educação, 5, 127-142.

Sanches, I. (2011a). Do 'aprender para fazer' ao 'aprender fazendo': As práticas de educação inclusiva na escola. Revista Lusófona de Educação, 19,157-163.

Sanches, I. (2011b). Em busca de unidades de registo de educação inclusiva. A "voz" dos professores de apoio sobre o que pensam, o que fazem e o que gostariam de fazer. Lisboa: Edições Universitárias Lusófonas. 
Slavin, R. (1991). Synthesis of research on cooperative learning. Educational Leadership, 48, 71-82.

Sprinthall, N., \& Sprinthall, R. (1993). Psicologia educacional - Uma abordagem desenvolvimentalista. Amadora: Editora Mc-Graw-Hill de Portugal.

Teodoro, A. (2006). Professores, para quê? Mudanças e desafios na profissão docente. Porto: Profedições.

Toledo, E., \& Vitaliano, C. (2010). Formação de professores em serviço por meio de pesquisa colaborativa, com vistas à inclusão de alunos com deficiência intelectual no ensino fundamental II. III Seminário de Educação Inclusiva: "Educação inclusiva: Do conceito às práticas", Universidade Lusófona de Humanidades e Tecnologias, 22 e 23 de Outubro.

UNESCO (1994). Declaração de Salamanca e enquadramento da acção na área das necessidades educativas especiais. Salamanca: UNESCO. 


\title{
MANAGING DIVERSITY: BENEFITS OF COOPERATIVE LEARNING TO BUILD INCLUSIVE CLASSROOMS
}

\begin{abstract}
The action-research we have held at the primary education, in a school placed near the town of Tomar, in 2009-2010, under the master's degree in Special Education, was the starting point for writing this article. The research had as main objective to promote the successful learning of a heterogeneous group of students, where a child considered with longstanding special educational needs is included - diagnosis of galactosaemia and cognitive impairment. Starting from the educational context of a particular classroom of 2 nd and 3rd grades, where we were working as special education teacher, we had created an inclusive learning environment for each student in the class. Through effective collaboration between fellow teachers, we generated changes in methodologies, breaking with some traditional practices in the classroom, when regular teachers and special education are in the same learning space. By a systematic implementation of cooperative learning strategies among students, and applying qualitative data gathering techniques of research, before and after the intervention - interview, naturalistic observation, sociometry and documental research -, we have increased the quality and quantity of learning and promoted another way of 'looking to' the difference.
\end{abstract}

Keywords

Inclusion; Diversity; Cooperative learning; Action-research 


\section{GÉRER LA DIVERSITÉ: CONTRIBUTIONS DE L'APPRENTISSAGE COOPÉRATIF POUR CONSTRUIRE DES CLASSES INCLUSIVES}

\section{Résumé}

La recherche-action que nous avons réalisée, dans une école primaire, près de la ville de Tomar, en 2009-2010, a été le point de départ pour écrire cet article. Cette recherche a eu pour objet d'encourager le succès dans l'apprentissage d'un groupe d'élèves diversifié, où se trouvait une élève avec des besoins éducatifs spéciaux permanents. Au sein du contexte éducatif spécifique d'une classe de 2ème et 3ème années de l'enseignement primaire, nous avons intervenu dans le but de faire naître une ambiance éducative inclusive pour chacun des élèves de la classe. Par une réelle coopération entre des enseignants cointéressés, nous avons réussi à produire des changements au niveau des méthodologies, tout en brisant quelques pratiques traditionnelles, au moment où se rencontrent, dans le même espace pédagogique, le professeur de la classe et celui d'éducation spéciale. Tout en utilisant des stratégies de l'apprentissage coopératif avec les élèves et des techniques de recherche qualitative pour la collecte d'information, avant et après l'intervention - interview, observation naturaliste, sociométrie et recherche documentaire -, nous avons accru la qualité et la quantité de savoirs et nous avons réussi à créer une autre façon de 'regarder' la différence.

Mots-clé

Inclusion; Diversité; Apprentissage coopératif; Recherche-action

Recebido em Agosto/2011

Aceite para publicação em Maio/2013

Toda a correspondência relativa a este artigo deve ser enviada para Isabel Sanches: isabelrsanches@gmail.com 